\title{
Archaeology of Trade in the Western Indian Ocean, 300 BC-AD 700
}

\author{
Eivind Heldaas Seland
}

Published online: 2 April 2014

(C) The Author(s) 2014. This article is published with open access at Springerlink.com

\begin{abstract}
In the millennium after $300 \mathrm{BC}$, the western Indian Ocean emerged as a main hub of Old World exchange. Study of this commerce long depended on separate regional archaeologies and a handful of literary sources with Western/Roman bias. A recent surge in scholarly interest has led to a vast increase in data that has fostered a more balanced understanding of the commercial, human, and material aspects of ancient Indian Ocean trade. This review summarizes recent research on the topic and assesses its significance to wider scholarly debates on scale, organization, connectivity, agency, and social cohesion in ancient trade and exchange.
\end{abstract}

Keywords Western Indian Ocean · Trade $\cdot$ Exchange $\cdot$ Connectivity Identity · Early Historic period · Pre-Islamic period · Classical period . Late antiquity

\section{Introduction}

On rare occasions, even modern archaeology takes on the characteristics of exploration and sensational discovery. One such event occurred in late 2000, when Belgian speleologist Peter De Geest and his team stumbled upon an ancient sanctuary deep inside the Hoq cave on the northeast coast of Socotra. The sanctuary contained a large number of graffiti in South Arabian, Indian Brahmi, Ethiopic Ge'ez, and Greek script, as well as an inscribed tablet in Palmyrene Aramaic, giving a date corresponding to AD 257-258 (Dridi 2002; Robin and Gorea 2002; Strauch 2012; Strauch and Bukharin 2004). Present-day Socotra is among the most isolated places in the world. In the centuries around the turn of the first millennium AD,

E. H. Seland (ه)

Department of Archaeology, History, Cultural Studies, and Religion, University of Bergen,

P.O. Box 7800, 5020 Bergen, Norway

e-mail: eivind.seland@ahkr.uib.no 
however, it was a crossroad of commerce based on the monsoon winds. This trade brought together people from all coasts of the western Indian Ocean, dealing in aromatics, spices, textiles, gems, glass, metal, slaves, grain, timber, and a range of other commodities of prestige and subsistence. The discovery of the cave sanctuary on the seemingly remote island provided not only an evocative reminder of the multicultural nature of ancient world trade, but also emphasized that the western Indian Ocean was never a barrier to contact; rather it is the proximate and natural medium of communication for people living along its rim.

For this article, I gather the different strands of research published over the last 20 years and identify the main accomplishments of the joint scholarly effort during this period. After a summary of early scholarship, I review regional points of view, with brief surveys of recent publications focusing on South Asia, the Persian Gulf, South Arabia, Socotra, East Africa, and the Red Sea. I then address the combined evidence for ships, navigation, and people, before discussing the contributions of western Indian Ocean archaeology to our understanding of early exchange in general, with regard to key issues such as scale, organization, connectivity, agency, and social cohesion. I owe much to recent syntheses on the topic (Beaujard 2012; Ray 2003; Sidebotham 2012; Tomber 2008). I depart from these works, however, in my scope as a review of recent research, rather than an analysis of the underlying research questions. My intent is to assess the place of western Indian Ocean archaeology within the wider discourse on ancient exchange. For reasons of space and coherence, my literature review concentrates on the western part of the Indian Ocean world: Arabian Sea, Persian Gulf, Gulf of Oman, Gulf of Aden, and the Red Sea (Fig. 1); coverage of the Bay of Bengal and the eastern Indian Ocean is intentionally limited. Similarly, although literature relevant to the Neolithic through modern periods is cited, my emphasis is on the millennium after circa $300 \mathrm{BC}$. This timeframe encompasses what would in South Asian chronology roughly correspond to the Early Historic period and to the pre-Islamic period from the Hellenistic era onward in the Persian Gulf and the Red Sea. I include results from complementary disciplines of philology and history only when they relate directly to material evidence and/or to the archaeological sites that are discussed. Selected titles on these related periods, regions, and subjects are included in the bibliography of recent literature at the end of the article.

\section{Scholarly origins}

Early modern travelers in the Indian Ocean knew their Periplus of the Erythraean Sea (Della Valle et al. 1665, p. 5; Niebuhr 1774, p. 452), the anonymous firstcentury Greek guide to travel and navigation in the Indian Ocean that still remains important in modern historiography (Casson 1989). British colonial administrators in India were well versed in classical sources describing the Indian Ocean (McCrindle 1979; Vincent 1998) and meticulously recorded finds of Roman coins from an early date (Ray 2008, pp. 189-190; Turner 1989, pp. 1-3). Western 19thcentury travelers and soldiers in Arabia and East Africa started connecting the ancient remains they encountered on their travels with toponyms familiar from the 


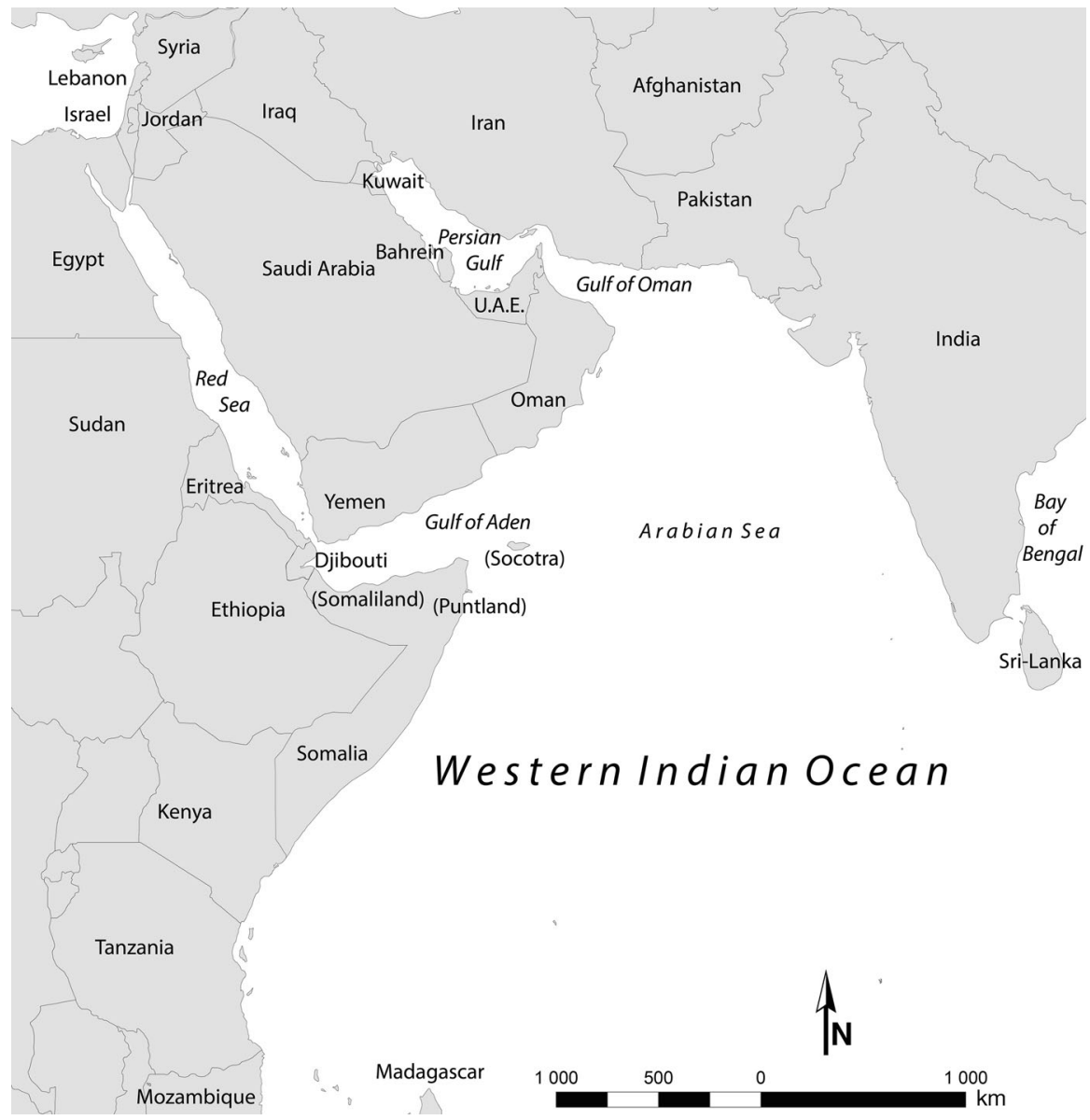

Fig. 1 Present-day political borders and geographical subdivisions in the western Indian Ocean region (map drawn by author)

Bible and classical accounts (Bent and Bent 1900; Wellsted 1838; Wellsted and Ormsby 1840). Also, European historians of the classical world were well aware of the literary and numismatic evidence of contacts with the East (Charlesworth 1926; Mommsen 1904; Warmington 1995). The archaeology of Indian Ocean trade in any modern sense of the word, however, started only in 1940, when Jouveau-Dubreuil published a short note on finds made at the site of Arikamedu, just south of Pondicherry on the Indian Coromandel coast. Among them was an intaglio engraved with the portrait of the first Roman emperor, Augustus (27 BC-AD 14) (Begley et al. 1996, pp. 2-3; Jouveau-Dubreuil 1940). The site became famous with the excavations undertaken by the Archaeological Survey of India, directed by Wheeler in 1945 (Wheeler et al. 1946), which were continued under the direction of Casal from 1947 to 1950 (Casal 1949; Casal and Casal 1956). In their report, Wheeler and his colleagues dubbed Arikamedu an Indo-Roman trading station on the east coast 
of India. The "Indo" part of the subtitle, however, appears largely to have been overlooked. Attention soon centered on artifacts of Mediterranean origin in the Indian Ocean world, which also were seen as evidence of Mediterranean presence, well assisted by Wheeler's (1955) best-selling popular account, Rome beyond the Imperial Frontiers. Arikamedu is situated on the eastern seaboard of India. Nevertheless, the influence of the site on the archaeology of exchange in the western Indian Ocean can hardly be overstated, as the stratigraphy, chronology, and arguably also the research agenda established at Arikamedu soon became pattern for sites excavated elsewhere (Gupta 1996, p. 51).

The sunset of colonial archaeology thus became the wellspring of the archaeology of Indian Ocean trade (Ray 2008, pp. 187-212), but things might have turned out differently. In early 1952, the team of the American Foundation for the Study of Man had to hastily abandon their excavations of the sanctuary Mahram Bilqis in Marib in Yemen, but they were invited to set up operations in Oman (Phillips 1955, pp. 224-238, 300-227). There, the site of Khor Rori, near presentday Salalah, was excavated during the following year, but unfortunately, the final report was almost 30 years in the making (Albright 1982). Although it could be argued that the nascent discipline of South Arabian archaeology, as other branches of Oriental archaeology, was as indebted to biblical archaeology as Wheeler had been to provincial Roman archaeology, it was a discipline with a clear regional commitment. Khor Rori boasts imposing walls and storehouses, monumental South Arabian inscriptions, and material evidence of a balanced network of contacts with India, the Gulf, and the Mediterranean, but primarily with the Hadramawti heartland (Avanzini 2002, 2008). If Khor Rori had become the prototype of an Indian Ocean port community, rather than the poorly understood Arikamedu, Indian Ocean archaeology might have started out on a different trajectory.

The study of exchange flourished within theoretically and anthropologically oriented archaeology in the 1970s (Earle and Ericson 1977; Renfrew 1977; Sabloff and Lamberg-Karlovsky 1975), but this had little visible impact on archaeologists working in the Indian Ocean. In the early postcolonial period, newly founded national archaeological services and foreign missions in the Indian Ocean region concentrated on establishing national subdisciplines. The Ethiopian excavations in Adulis in present-day Eritrea in 1960-1961 (Anfray 1974), in retrospect another example of colonial archaeology, was the only major project with relevance in a wider Indian Ocean setting. At the same time, many classical archaeologists, working in the tradition of Wheeler and in the parts of the Indian Ocean world that had been subject to Hellenistic and Roman rule, turned their attention away from trade after the devastating criticism of the modernist/formalist tradition voiced by Finley (1973) in Ancient Economy. Similarly, many anthropologically oriented scholars, disenchanted with neo-evolutionary approaches to (see Yoffee 2005), turned toward the study of indigenous agency and trajectories of development. In sum, this left the study of ancient Indian Ocean trade to scholars who, whether they were archaeologists, classicists, Arabists, Indologists, or Orientalists by training and inclination, did not engage critically with the notion that early historiography had established that ancient Indian Ocean trade was in essence Roman trade with the East. When Raschke (1978) published his critical 700-page review of overland and 
maritime connections between Asia and the Roman Empire, he found easy targets in conclusions that were inferred from meager sources and an archaeological record biased toward Mediterranean material.

Renewed interest in Indo-Roman as well as regional approaches to the archaeology of the western Indian Ocean trade began in the 1980s and grew throughout the 1990s, with the launching of several important survey and excavation projects. Also, Casson's (1989) translation of and commentary on the Periplus of the Erythraean Sea made this key text available for the first time in a modern, scholarly edition. After the turn of the millennium, it increasingly makes sense to speak of archaeology in the western Indian Ocean as an integrated field, where the different regional archaeologies of the Indian Ocean rim, including the very significant parts controlled by the Roman Empire, give their share to a holistic understanding of the ancient exchange systems based on the monsoon winds.

\section{South Asia}

Arikamedu (Fig. 2) was not only the birthplace of Indian Ocean archaeology, but it also became the point of departure for the renewed interest in the material evidence of Indian Ocean trade. This started with new studies of the material that was excavated but only partly published by Wheeler and Casal (Begley 1983; Begley et al. 1996, p. 7; Gupta 1996) and continued with new excavations directed by Begley from 1989 to 1992 (Begley 1993; Begley et al. 1996, 2004). It became clear that the site had a much longer and more complex history of occupation than the original excavators had believed, not confined to the first two centuries AD, but stretching at least from the second century BC to the 10th century AD (Begley et al. 1996, pp. 8-40). Francis (1991) demonstrated the site's important role in the production of Indo-Pacific beads, thus highlighting its eastward connections along and across the Bay of Bengal and the diversity of trading links. The widely distributed Rouletted Ware, first identified at Arikamedu but since found at approximately 150 sites, including at least 11 outside South Asia (Schenk 2006, pp. 142-146), was originally interpreted as strongly inspired by Mediterranean patterns (Wheeler et al. 1946). It has since been shown to develop out of regional traditions in South Asia, spanning back at least to the second century BC. It is thus unrelated to the monsoon trade with Roman-period Egypt (Begley 1983, 1988; Ford et al. 2005; Magee 2010; Ray 1994, pp. 59-61), although it may have been inspired by Hellenistic-period pottery encountered in Mesopotamia and the Persian Gulf (Magee 2010; Ray 1994, pp. 59-61; Salles 2002, pp. 197-199). Even if the significance of the Mediterranean connection has been played down over time, Arikamedu has retained its position in the study of Indian Ocean trade. Beads as well as pottery associated with the site have become highly useful proxies for tracing trading connections, emphasizing the centrality of South India and Sri Lanka in connecting the Arabian Sea and Bay of Bengal circuits of trade (Gupta 2005; Pavan and Schenk 2012). The new studies and excavations at Arikamedu clearly show a site with a much wider significance in terms of chronology and commercial 


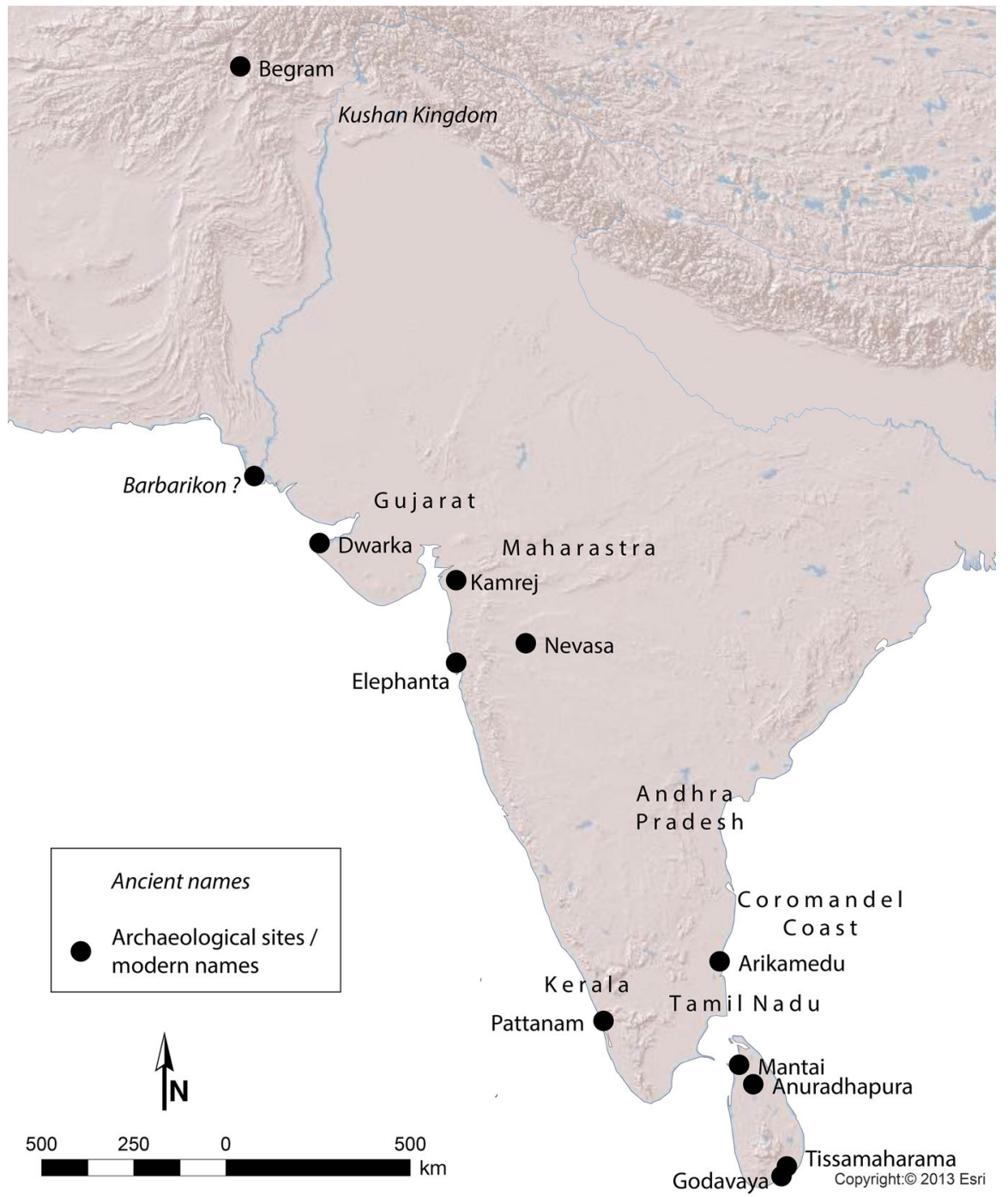

Fig. 2 South Asian sites and places mentioned in the text (map drawn by author, base map C ESRI 2013, used with permission)

as well as cultural diversity than the "Roman factory" inferred by Wheeler, but they have not yet revealed much about the socioeconomic organization of the ancient port (Tomber 2008, pp. 147-151).

Arguably the most important Indian site excavated after Arikamedu is Pattanam, generally identified with the port of Muziris, mentioned in Roman as well as Tamil literary sources (Shajan et al. 2004). The Kerala Council for Historical Research has excavated at Pattanam since 2007. Along with locally produced pottery and beads, finds include building structures, a wharf, a log boat, imported Mediterranean glass, 
Roman Terra Sigillata pottery, and a range of amphorae (Mediterranean transport jars), all dating to the first century BC through the second century AD. Specimens of Sassanian-period (AD 224-651) torpedo jars from Mesopotamia, late Roman (fifth to seventh centuries) Aila/Aqaba amphorae, glazed Partho-Sassanian pottery, and sherds of probable South Arabian origin also are reported (Cherian 2011; Cherian et al. 2007, 2009; Selvakumar et al. 2009; Tomber 2009).

While the link to textual sources and the massive evidence of trade in bulk commodities and luxury items have brought well-deserved attention to Pattanam, the site is only one of many along the coasts of Pakistan, India, and Sri Lanka. By 2008, evidence of commercial contacts with the Red Sea and the Persian Gulf had been recorded from 36 sites in the form of Roman and late Roman amphorae and Mesopotamian torpedo jars (Tomber 2007b, 2008, pp. 126-127, 176). Sites are distributed all over South Asia, with clusters on the coasts of Gujarat, Maharastra, South India, Sri Lanka, and Andhra Pradesh. Such early historical ports as Dwarka (Gaur et al. 2006), Kamrej (Gupta et al. 2004), and Elephanta Island (Tripathi 2004), as well as the inland center of Nevasa (Gupta 1998; Gupta et al. 2001), do not figure prominently in literary sources but nevertheless appear to have been significant focal points of regional and long-distance exchange (see also Smith 2002). Imported pottery is not limited to Mediterranean and Mesopotamian wares but also include vessels of Arabian (Selvakumar et al. 2009, p. 34) and probably Aksumite origin (cf. Phillipson 2011, p. 200; Tomber 2005). Their presence demonstrates not only a multiplicity of routes, ports, and carriers but also the durability and longevity of commercial contacts with the western Indian Ocean throughout the Indian Early Historic period (c. 300 BC-AD 500) and into the early medieval period.

Along with South India, Sri Lanka enjoys a privileged geographical position as a natural juncture between Arabian Sea and Bay of Bengal networks (Bandaranayake 1990). Still, the island long remained underexplored archaeologically with regard to Indian Ocean trade. References in literary sources (Weerakkody 1997) and large finds of late Roman bronze and copper coins, also found in South India and apparently imported in bulk (Bopearachchi 1992, 1998), long gave the impression that the island did not emerge as an important node in commerce with the Persian Gulf and the Red Sea until the fourth to sixth centuries AD. Excavations at Tissamaharama, along with studies of ceramics from Mantai and Anuradhapura (Carswell 1991; Carswell et al. 2013; Coningham 2002, 2006; Coningham et al. 1996; Coningham and Raymond 1999; Ford et al. 2005; Pavan and Schenk 2012; Schenk 2001, 2006, 2007), however, have demonstrated that the island's nodal role can be traced back at least to the third century BC. The ship cargo of the second to first centuries AD that was discovered in 2008 off the ancient port of Godavaya in southern Sri Lanka is still under excavation, but preliminary publications and news reports have announced finds of glass ingots and metal, possibly of Indian provenance (Carlson 2010; Lawler 2012). This is only the second ancient shipwreck discovered in the western Indian Ocean, so it is hoped that the ongoing excavations will contribute to our understanding of technology and the organization and commodities of Indian Ocean trade. 


\section{Persian Gulf and Gulf of Oman}

Gulf archaeology (Fig. 3) has a long record as a robust regional archaeological discipline, but thus far relatively few publications have approached Persian Gulf sites and material from an Indian Ocean perspective or vice versa (see, however, Kennet 2004; Salles 2012). Iron Age societies on the Arabian, Mesopotamian, and Iranian littorals of the Persian Gulf were tightly integrated in networks of political, cultural, and commercial nature (Magee 2005, 2010; Potts 2009, pp. 36-39). With Alexander's conquest of the Achaemenid Empire, large parts of the Gulf became part of the Hellenistic world, but little is known of the extent or organization of trade between the Persian Gulf and the Indian Ocean. The island of Failaka in present-day Kuwait has yielded considerable ceramic, epigraphic, and architectural evidence of Hellenistic settlement (Callot et al. 2005; Hannestad 1983; Jeppesen 1989). The location of the island at the head of the Persian Gulf and its limited local agricultural resources makes a connection of the settlement with commercial and/or naval activities likely. Sherds of Arabian Red-and-Black-Washed pottery reveal contacts with eastern Arabia (Hannestad 1983, pp. 49-50), while characteristic Nabataean ceramics show that the site took part in exchange along the Persian Gulf/ Mediterranean axis around the turn of the first millennium AD (Hannestad 1983, pp. 51-52) and corroborate the literary report of Nabataean merchants in the region (Pliny NH 6.145; see Rackham 1997-2001). Nabataean ceramics and coins also have been found at Thaj and Qatif (Potts 1991), revealing that this network extended into the Gulf. Greek, Hellenistic, and Roman coins are reported from a number of sites in eastern Arabia (Howgego and Potts 1992), although the mechanisms by which they arrived there are not known. Bahrain, with its strategic location halfway along the south-north axis of the Gulf, ample supply of water, and rich pearl resources, is likely to have been an important center of regional and interregional navigation and commerce. Tylos-period (fourth century BC to seventh century AD) cemeteries on the island have yielded hundreds of objects, documenting contacts with Mesopotamia, Iran, and Egypt (Andersen 2007; Salles 1993, pp. 124-126; 2012, pp. 319-322).

Thus far, however, only one major site of primarily commercial nature has been documented in the Persian Gulf, Ed-Dur in Umm al-Quwain (UAE). The site is frequently, but not securely, identified with the Parthian Gulf emporium of Omana, mentioned in the Periplus (sec. 36) (Potts 1997, p. 94, but see Mouton 2008, pp. 257-258). Results of the University of Ghent South-East Arabian Archaeological Project in the late 1980s and early 1990s have been published in detail. Glass, ceramics, and coins from funerary as well as residential settings show extensive commercial contacts with Mesopotamia, India, and the Mediterranean world, as well as other parts of Arabia and southern Iran (Haerinck 1998, 2001, 2011; Mouton 2008; Rutten 2007; Sidebotham et al. 2008; Whitehouse et al. 1998). Contacts with the Mediterranean probably took place by way of ports in South Arabia, such as Qana and Khor Rori, as well as from Mesopotamia and India, rather than directly overland or from the Red Sea (Rutten 2007). The impression that commerce was an 
important part of the basis for the settlement is strengthened by the fact that Ed-Dur is essentially a one-period site during the first and early second centuries AD (Haerinck 2001, pp. 4-5).

There is little evidence of widespread direct navigation between the Persian Gulf and the Red Sea in antiquity (Salles 1988). Thus South Arabia and Northwest India likely played key roles in connecting the Red Sea-Arabian Sea and Persian Gulf -Arabian Sea corridors of exchange. In addition to Ed-Dur, signs of this nodal role can be seen in Dibba al-Hisn and Mleiha in the emirate of Sharjah. Dibba al-Hisn on the east coast of the UAE has yielded Parthian, Roman, and Indian materials from funerary settings of the same period as Ed-Dur, making it an alternative location for ancient Omana (Jasim 2006). Finds from Mleiha, farther inland, include material of Indian, African, Iranian, and Mesopotamian origin, revealing that it also was connected to a comprehensive Indian Ocean network in the first centuries AD (Benoist et al. 2003; Mouton 2008). Rich finds of Indian Red Polished ware from Suhar in Oman date back to the start of the settlement, probably the first century AD (Kervran 1998, pp. 40-43). Finally, the late pre-Islamic and Early Islamic assemblages from the site of Kush in Ras al-Khaimah (UAE) provide evidence of contacts with Mesopotamia as well as India (Kennet 2004, pp. 69-71).

Contacts with the Gulf also are evident from Arabian Sea contexts. Mesopotamian torpedo jars of the Sassanian period are documented from a number of sites on the Indian subcontinent (Tomber 2007b), and Parthian pottery has been found in stratified settings in Tissamaharama, Sri Lanka (Schenk 2007). Other types of West Asian glazed pottery are reported from South Asia (Glover 2002) and South Arabia, including Khor Rori (Sedov and Benvenuti 2002, pp. 192-193).

In the first to third centuries $\mathrm{AD}$, merchants from the Syrian city of Palmyra, sailing out of the Mesopotamian kingdom of Mesene, were among the carriers of this trade (Potts 1997). Palmyrene inscriptions from the second century commemorate not only caravans to southern Mesopotamia and a Palmyrene acting as Satrap of Tylos (Bahrain) on behalf of the Mesenian king (cf. Gawlikowski 1994), but also merchants travelling by ship to the Kushan kingdom, presumably to the port of Barbarikon in present-day Pakistan (Delplace 2003). Tombs on the island of Kharg, present-day Iran, have been characterized first as Palmyrene (Ghirshman 1958, pp. 265-266) and later as Nabataean (Steve 2003, pp. 67-68); these identifications based on stylistic arguments should be considered tentative.

Along with the already cited ceramic evidence from the Indian subcontinent, literary sources indicate continued and flourishing trade between Iran, Mesopotamia, eastern Arabia, and the Arabian Sea in the Sassanian period (Daryaee 2009; Whitehouse 1996; Whitehouse and Williamson 1973). In Iran, the combined commercial and military/administrative sites of Siraf and Rishahr have yielded Red Polished ware from India and painted ceramics from the Minab region at the entrance to the Persian Gulf (Whitehouse 1996, pp. 341-342). Also, a fortress was maintained by the Sassanids at Qal'at al-Bahrain (Kervran et al. 2005). With regard to eastern Arabia, the general trend in the archaeological record is a decline in the number of settlements, burials, and coin finds compared to the Hellenistic and Parthian periods (Kennet 2007). 


\section{Southern Arabia and Socotra}

Southern Arabia (Fig. 3) played a key role in ancient Indian Ocean exchange. The region was a main supplier of frankincense and myrrh. These aromatics were utilized for religious, funerary, cosmetic, and medicinal purposes in India, the Persian Gulf, and the Mediterranean world. Southern Arabia also was important as a meeting point for maritime routes connecting the Red Sea, East Africa, India, and the Gulf, and merchants from Arabia took active part in maritime trade (Peacock et al. 2007b).

Politically, the inland mountains and major valleys (wadis) of southern Arabia were divided into a number of kingdoms based on a combination of irrigation and dry farming (Breton 1999; De Maigret 2002; Schippmann 2001; Simpson 2002). Several ports were maintained along the arid coastline. Two of these, Khor Rori in Oman and Qana in Yemen, have been extensively documented.

Khor Rori (ancient Sumhuram) was originally excavated by the American Foundation for the Study of Man in the 1950s and was long interpreted as an outpost established and maintained by the kingdom of Hadramawt for the control of the frankincense trade with the Roman world (Albright 1982). The site has seen renewed excavations and restorations by the Italian Mission to Oman since 1996. The new studies have established a much longer chronology for the settlement than was previously thought, starting in the fourth century BC and extending to the fifth century AD (Avanzini 2002, 2008; Avanzini and Sedov 2005). Pottery assemblages show contacts with India, the Persian Gulf, and the Mediterranean (Pavan 2007; Pavan and Schenk 2012; Sedov and Benvenuti 2002). The economic basis and settlement history of the site include local agricultural production, an extramural settlement, and a role in the metal trade with southeastern Arabia and the Persian Gulf. Nevertheless, the importance of frankincense production and trade for ancient Sumhuram has never been doubted (Avanzini 2002, 2008).

Farther west along the coast of South Arabia, near the modern village of Bir Ali in Yemen, ancient Qana was identified by Wellsted in 1834 and first surveyed by Doe (1961) in 1957. The site has been excavated by the Soviet and later the Russian Archaeological Mission to the Republic of Yemen in several campaigns since 1972, partly in cooperation with other international teams (Salles and Sedov 2010, pp. 2 3 ). The original reports are in Russian, and the site was long known mostly through shorter syntheses (Sedov 1992, 1998, 2007); the results of the excavations up to 1994 recently became available with related studies in French and English (Salles and Sedov 2010).

Ancient Qana consists of a fortress at the prominent hilltop of Husn al-Ghurab and a settlement of fluctuating size on the beach below that appear to have been established in the first century AD. The site likely was the main port of the early South Arabian kingdom of Hadramawt, which was arguably the main supplier of frankincense in the ancient world. The port continued in operation under Himyarite rule in late antiquity until the settlement was abandoned in the early seventh century (Sedov 2010b). Sedov connects the foundation and existence of Qana with the Hadramawti key role as a supplier of frankincense from South Arabia and Socotra in the monsoon trade with the Mediterranean, India, and the Persian Gulf (Sedov 2010b, pp. 453-454). 
Early in the site's occupation, imported ceramics, mainly Roman Dressel 2-4 transport amphorae but also Dressel $1 \mathrm{~b}$ and Dressel 7-11 amphorae carrying primarily wine but probably also garum (fish sauce), and possibly wheat, show extensive contacts with the Mediterranean economy. Green-glazed pottery and storage jars of Black-and-Grey ware reveal commercial connections with the Persian Gulf and southeastern Arabia (Sedov 2010b, pp. 462-463). Connections with the Mediterranean continued between the late second to early fifth century AD at the same time that imported objects show increased contact with the Persian Gulf and, to a limited extent, also with India and southeastern Iran (Sedov 2010b, pp. 463-465). More extensive architectural remains characterize the settlement at that time, indicating development from a place of seasonal exchange to a commercial city. In one of the structures from this period, a Greek-language graffito of monotheistic, probably Jewish, content was found (Bowersock 1993). A building, which may be identified as a synagogue on architectural grounds, was later erected on the site (Sedov 2010a). In addition to lending material context to the rise of monotheism in southern Arabia as known from literary sources, these finds are suggestive of the multicultural nature of Indian Ocean commerce and open questions of continuity with the better-documented Jewish diaspora of the medieval period and of the role of religion in early Indian Ocean trade.

The size of the settlement was again reduced in the sixth to early seventh centuries. Sherds from Aqaba in present-day Jordan and the Aksumite kingdom in Ethiopia/Eritrea dominate the record of imported ceramics, reflecting growing Aksumite importance in Red Sea and Indian Ocean exchange as well as Aksumite imperial ambitions in southern Arabia at that time (Sedov 2010b, pp. 465-466).

The island of Socotra, due east of Cape Guardafui, is today part of the Republic of Yemen (Fig. 4). According to the Periplus (sec. 31), it also was controlled from the Arabian mainland in the first century AD, when it was ruled by the kings of Hadramawt. Socotra is home to such plants as aloe, Dragon's blood (Dracaena cinnabari), and frankincense (genus Boswellia, several species) (Cheung et al. 2006, pp. 87-90). These crops were commercially important in antiquity and were almost certainly exploited. The island lacks harbors and mooring places sheltered from the summer (southwestern) monsoon. Until the opening of a commercial airport in 1999, Socotra was not easily accessible and long remained a blank spot on the archaeological map of the Indian Ocean. Shinnie (1960, p. 103) visited Socotra as part of the Oxford University expedition in 1956 and noted walled and terraced parcels of land that he tentatively connected with ancient cultivation of aromatics (but see Weeks et al. 2002, pp. 120-122). Doe (1970) conducted the next archaeological survey in 1967, recording visible architectural structures. The Russian Archaeological Mission to the Republic of Yemen has been active on the island since 1983, surveying and excavating the settlement of Hajriya, located inland of the modern village of Suq on the northern coast. Their results have yielded the first material with a relationship to ancient Indian Ocean exchange. Although the surveyed structures were dated to the 10th through 13th centuries, surface finds include ceramics dating to the first through fourth centuries AD that were imported from the Mediterranean, southern Arabia, the Persian/Arabian Gulf, and possibly India; these materials are similar to those from stratified layers of the third and 
fourth centuries at Qana (Naumkin and Sedov 1995, pp. 224-229). Further evidence of maritime contacts of the pre-Islamic period were discovered in 2010 during a Russian survey at Kosh, near the western point of the island, where surface pottery assemblages also revealed close affinities to material excavated at Qana (Vinogradov 2011). Along with the spectacular epigraphic record of approximately 250 inscriptions from the Hoq cave (Dridi 2002; Robin and Gorea 2002; Strauch 2012; Strauch and Bukharin 2004), these finds now place Socotra as a major node in the pre-Islamic Indian Ocean network. The fact that the island altogether lacks suitable natural harbors makes this all the more interesting; this apparent contradiction could perhaps be approached through studies of ship technology or the seasonality of trade.

Khor Rori, Qana, and the sites on Socotra are all materially, epigraphically (partially), and historically affiliated with the early South Arabian kingdom of Hadramawt, centered in the eastern part of present-day Yemen. Literary sources record that other South Arabian kingdoms also took part in maritime trade (Schiettecatte 2012), most importantly Saba-Himyar, which came to control the Arabian side of the Bab al-Mandab and the straits separating the Red Sea and the Gulf of Aden-the area where the Himyarite empire evolved during the third century. Imported late Roman Aila/Aqaba amphorae are reported from the German excavations at the Himyarite highland capital of Zafar (Damgaard 2009, pp. 87-88; Raith et al. 2013), but thus far pre-Islamic port sites, with the exception of Aden, which is completely covered under later habitation, have not been securely identified, much less surveyed or excavated.

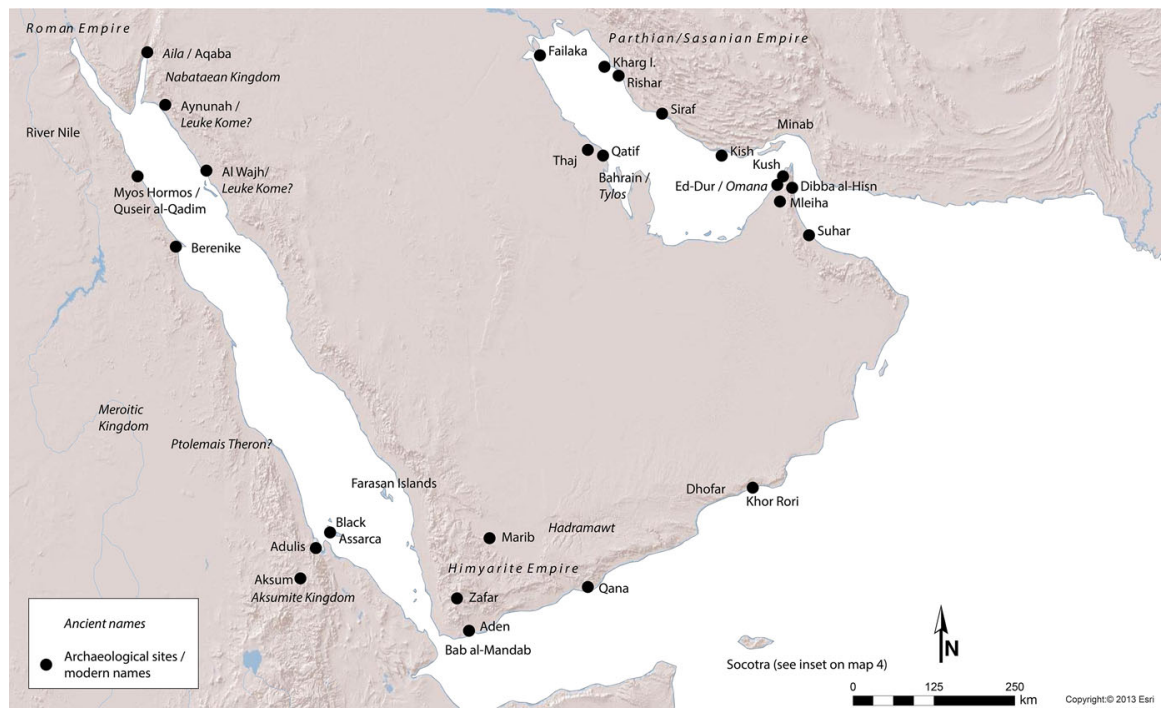

Fig. 3 Persian Gulf, Arabian Sea, and Red Sea sites and places mentioned in the text (map drawn by author, base map (C ESRI 2013, used with permission) 


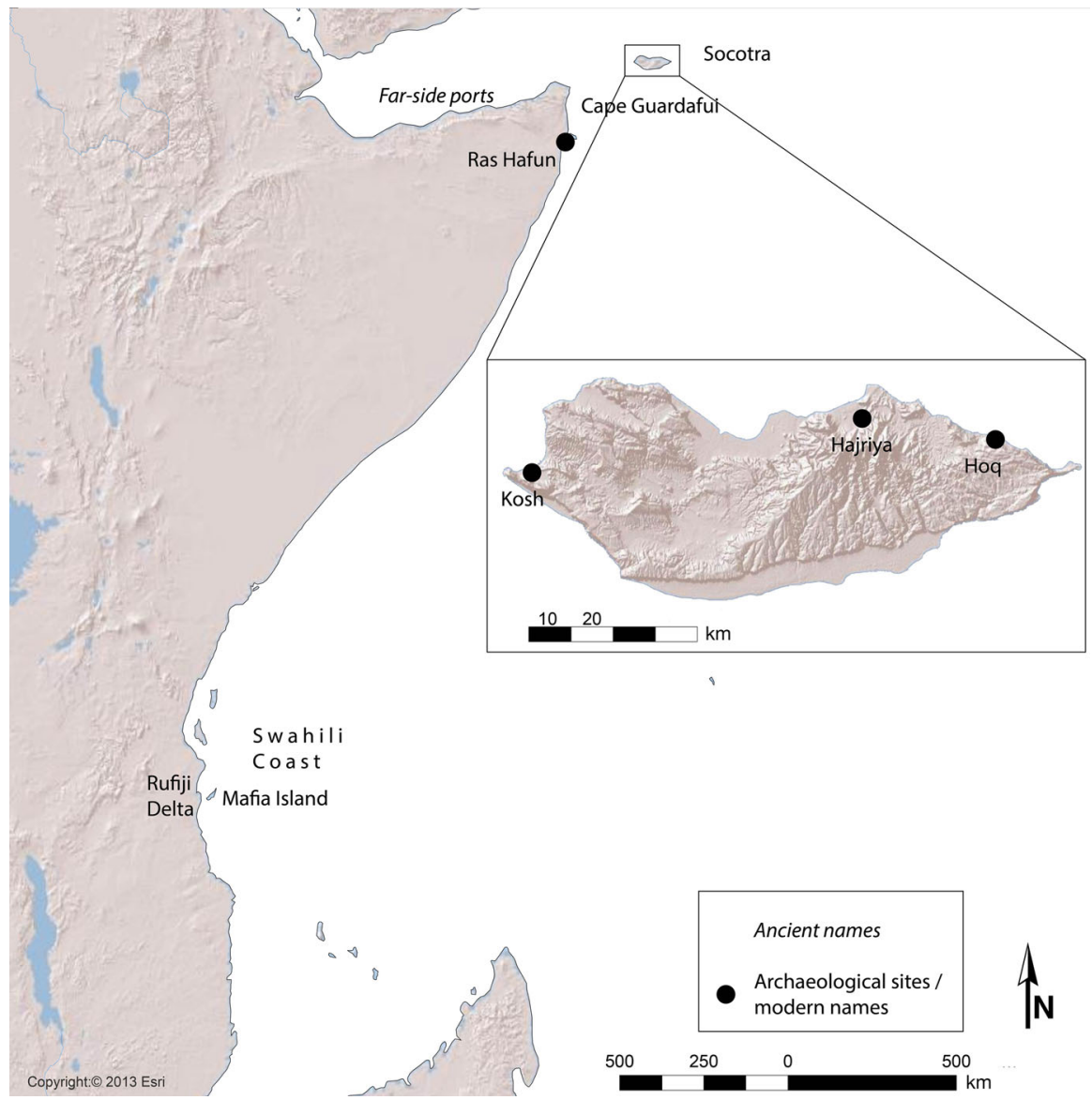

Fig. 4 East African and Socotra sites and places mentioned in the text (map drawn by author, base map (C) ESRI 2013, used with permission)

\section{East Africa}

Another underexplored part of the Indian Ocean rim with regard to early maritime exchange is East Africa (Fig. 4). The Swahili coast is famous for its role in the Indian Ocean exchange from the late first millennium AD onward (Horton and Middleton 2000; LaViolette 2008; Shipton et al. 2013; Walz and Gupta 2013), but there is an ongoing and unresolved debate on the role of this region during the first millennium. Extensive fieldwork, especially along the coast of Tanzania, but also in Kenya and Mozambique, has shed light on settlement in the early Iron Age period (Chami 2004, 2005; Chami and Msemwa 1997). The formation of urban centers along the coast was clearly under way toward the end of this period (Juma 2004; Sinclair 1982); external contacts are evidenced for instance by the presence of imported beads (Wood 2012). Claimed material evidence of early first millennium or earlier contacts with the Indian Ocean system from sites on Mafia Island and in 
the Rufiji Delta (Chami 1999, 2005) has, however, been met with skepticism (Helm et al. 2012; Horton and Middleton 2000), and interest has been directed toward studies of mobility as evidenced by genetics, linguistics, and the movement of crops (Beaujard 2011; Boivin et al. 2012; Fuller et al. 2011; Helm et al. 2012). These approaches have provided considerable new insight into the long-term dynamics of the Indian Ocean system (Boivin et al. 2010) and on the later-period archaeology of East Africa. It might be anticipated that they also will shed more light on the East African coast during the first millennium.

The author of the Periplus knew of the ports on the coast of Somalia as "the farside ports" (Greek: ta peran emporia), signifying their situation either outside Bab al-Mandab (from a Red Sea point of view) (Casson 1989, pp. 55, 59, 115) or perhaps equally likely opposite the coast of southern Arabia. Arab, Indian, and Egyptian traders visited these ports in search of frankincense and other aromatics. For political and security reasons, the coast of Somalia has been effectively closed to archaeologists since the start of the civil war in 1991 (Mire 2011). The British Institute in East Africa conducted some exploratory work before that (Chittick 1969, 1976, 1979), and Chittick directed excavations at the site of Ras Hafun, south of Cape Guardafui in 1976 (Smith and Wright 1988). Published results emphasize evidence of contacts with the Mediterranean world, but Mesopotamian and Indian ceramics also were recorded (Tomber 2008, pp. 159-160). Provided there are stable political conditions, Somaliland and Puntland in northern Somalia are among the most promising areas for future archaeological work on ancient Indian Ocean trade (Mire 2011); because of the arid environment there also is potential for aerial or satellite approaches like those recently applied with success on the Arabian Peninsula (Kennedy 2011; Kennedy and Bishop 2011).

\section{The Red Sea}

In contrast to East Africa, the Red Sea (Fig. 3) has experienced an explosion of scholarly interest since the 1990s. Key sites such as Adulis, Berenike, and Myos Hormos have seen major archaeological investigations, and a series of Red Sea conferences under the auspices of the Society for Arabian Studies has brought together scholars from different disciplines with a common interest in the region and have resulted in numerous publications.

Adulis, on the coast of present-day Eritrea, was the main coastal settlement of the kingdom of Aksum and was occupied from the first millennium BC to the early Islamic period. Early explorers and excavators identified the site and documented monumental structures-palaces and churches-connected with its late phase of occupation (Anfray 1974; Munro-Hay 1989; Paribeni 1907; Sundström 1907; Zazzaro 2013). New fieldwork took place in 2004-2005 as a part of an EritreoBritish project, which located the probable site of the middle-late Aksumite-period port, as well as the first century AD mooring place indicated in the Periplus, unknown until then (Peacock and Blue 2007a, b; Peacock et al. 2004). Surface ceramics show a range of vessels from the Mediterranean world, with an emphasis on the late period, and amphorae of the Aila/Aqaba type which also are found at 
Qana, Zafar, and Aksum. Significant import of Mediterranean marble also can be traced (Peacock and Blue 2007a, pp. 37, 79-108, 130). An Eritreo-Italian team resumed excavations at Adulis in 2011; their preliminary findings of regionally produced Adulitan ware from stratified levels show not only a localized ceramic tradition but also that the site has a settlement history stretching back into the first millennium BC (Zazzaro and Manzo 2012). Near the island of Black Assarca, off the coast and north of Adulis, the recovery of the cargo of a small sixth/seventhcentury merchant ship revealed large numbers of Aila/Aqaba amphorae and also globular pilgrim-flask-type amphorae from kilns at Aila (Pedersen 2008). Together with results from the Aksumite capital in the highlands of present-day Ethiopia (Munro-Hay et al. 1989; Phillipson 1998, pp. 63-70, 2011, pp. 195-200; Wilding 1989), the finds reinforce the impression long prevalent in the scholarly literature of the Aksumite kingdom as an actor in ancient Indian Ocean exchange from the first century AD onward but with increased importance in the fourth to early seventh centuries. In this period, literary sources imply Aksumite attempts to control the southern Red Sea and the transit trade between the Red Sea and the Arabian Sea. The prominent presence of ceramic transport vessels from Aqaba points toward that port being the main northern trading partner of late period Adulis.

No pre-Islamic port has yet been securely identified along the African coast between Adulis in Eritrea and Berenike in present-day Egypt. Literary and papyrological documents show that the shoreline was the target of Ptolemaic elephant-hunting expeditions (Casson 1993; Sidebotham 2011, pp. 39-53), and evidence of Meroitic contacts with the Indian Ocean (Håland 2013) should be present along the coast of present-day Sudan. Discussions on the location of the arguably most important of these ports, Ptolemais Theron, still rely on literary evidence (Bukharin 2011), and few advances have been made on the ground since Crowfoot's (1911) survey published more than a century ago.

Egyptian Berenike was established in the third century BC as a part of the Ptolemaic effort to access Red Sea resources. The port experienced peaks of operation in its early days, in the first century AD and again in the fourth and fifth centuries, with limited evidence of activity before or after. The site was abandoned by the mid-sixth century (Sidebotham 2011; Sidebotham et al. 2008, pp. 171-175). Berenike was excavated from 1994 to 2001 by a joint American-Dutch team headed by Sidebotham and Wendrich (1995, 1996, 1998, 1999, 2000, 2007). New work has been undertaken since 2008 by an American-Polish team led by Sidebotham and Zych (2010, 2011, 2012a).

Berenike has extraordinary conditions of preservation and minimal later disturbance, and extensive and long-standing archaeological work at the site has yielded results that are too voluminous to be discussed here in detail (recent syntheses include Cappers 2006; Sidebotham 2011; Wendrich et al. 2003). Among the important results are traces of the Ptolemaic period harbor, including infrastructure tentatively connected with the transit of live elephants trapped in the African Red Sea hills for purposes of war (Radowską and Woźniak 2011; Sidebotham and Zych 2010, pp. 10-11, 2012a, p. 31). Berenike has so far yielded evidence of 12 written languages, including South Arabian, Palmyrene Aramaic, and Tamil-Brahmi (Sidebotham 2004; 2011, pp. 74-75; Sidebotham and Zych 2010, 
p. 12). A considerable number of Greek texts on ostraca, papyri, and other media that shed light on everyday life and economic transactions at the port have been published (Bagnall et al. 2000, 2005). Imported ceramics include vessels from India, South Arabia, and Aksum (Begley and Tomber 1999; Tomber 2000, 2012). While conclusions on ethnicity are difficult to infer, Roman Berenike reinforces the cosmopolitan impression of ancient Indian Ocean exchange from the cave sanctuary of Hoq on Socotra. Buildings from Berenike show reuse of Mediterranean-style ship timbers from Indian teak, revealing that vessels were built or repaired in India in Mediterranean mortise-and-tenon tradition or alternatively that they were built in Egypt from imported wood (Sidebotham 2011, pp. 203-205; Sidebotham and Wendrich 2007, p. 290). Textiles that have been recovered include cottons woven from Z-spun yarns, and thus probably of Indian origin, and fragments of sails woven in Mediterranean style (Wild and Wild 2001, 2007). Finally, Berenike has yielded a rich archaeobotanical record, including the spectacular find of an Indian-made vessel resembling a dolium-type transport jar containing $7.55 \mathrm{~kg}$ of black pepper (Piper nigrum) imported from South India. Other finds show contacts with the Nile Valley, the Mediterranean, South Asia, Arabia, and the East African coast (Cappers 2006). The Berenike teams and other groups have completed considerable surveys and excavations at sites between the Nile River and the Red Sea, shedding light on the land-based infrastructure connected with maritime trade (Sidebotham et al. 2008).

To the north along the Egyptian Red Sea coast, Myos Hormos (Islamic-period Quseir al-Qadim) was the second major Egyptian port in the Indian Ocean/Red Sea trade. The University of Chicago excavated the site in 1978, 1980, and 1982 (Whitcomb and Johnson 1979, 1982), but the main results relevant to the preIslamic period come from the University of Southampton excavations from 1999 to 2003 (Blue 2007; Peacock and Blue 2006, 2011). Myos Hormos is also likely to have been a Ptolemaic settlement, but apart from a few Hellenistic coins, no other traces from this period have been identified (Peacock and Blue 2006, 2011, p. 345). Maritime activities in the port were their busiest following the construction of a wharf built of amphorae, earth, rocks, and ceramic debris late in the first century BC or early in the first century AD, (Blue 2011; Peacock and Blue 2006, pp. 67-94). The site shows no signs of permanent occupation after the mid third-century (Peacock and Blue 2006, pp. 174-175).

Finds from Myos Hormos partially parallel those from Berenike, and the sites together contribute to what is arguably a fairly robust impression of Roman-period Red Sea and Indian Ocean trade seen from an Egyptian perspective. Archaeobotanical materials document imports from the Indian Ocean region, including rice and black pepper (Veen et al. 2011a, b). Basalt carried as ballast that has been found at Myos Hormos and Berenike has been shown to originate from South Arabia and probably was imported from the ports of Qana and Aden (Peacock et al. 2007a). Fragments of Roman glass, already amply documented during the Chicago excavations (Meyer 1992), were abundant in trash dumps (Peacock 2011). Close parallels exist with the sealed storerooms discovered in the ancient Kushan capital of Begram, Afghanistan, in 1937 and 1939, revealing the ultimate destination of some of the glass exported from the Red Sea ports (Mairs 2012; Mehendale 2011; 
Menninger 1996; Whitehouse 1989, 2001). Pottery with texts in South Arabian, Palmyrene Aramaic, and Tamil-Brahmi echo the heterogeneous cultural environment of Berenike (Tomber 2011), and ceramics from the Adulis area also have been found (Tomber 2012, p. 204).

A major breakthrough of the excavations at Egyptian Red Sea ports is that ship fittings from Myos Hormos and timbers from Berenike document that at least some of the vessels operating out of Egyptian Red Sea ports were of the type common in the Mediterranean (Blue 2009; Blue et al. 2011; Sidebotham and Zych 2010, pp. 19-20). As in Berenike, remains of sails from Myos Hormos show Mediterranean patterns combined with Indian fibers and techniques (Handley 2011).

While Myos Hormos was abandoned by the third century, Berenike enjoyed a period of renewed prosperity from the fourth century (Sidebotham 2002; Sidebotham and Zych 2012b, pp. 140-143, 152). The overall trend, however, seems to be that ports of the northern Red Sea became more important in late antiquity. This is partly visible in the fragmented literary record from the period (Decker 2010, pp. 204-208; Ward 2007) but also in the presence of late Roman/ early Islamic amphorae that have been shown to originate from kilns in Aila (Aqaba) in present-day Jordan (Parker 2009; Whitcomb 2001). These are reported from sites along the Red Sea (Damgaard 2009, pp. 87-88; Peacock and Blue 2007a, pp. 79-108, 130; Pedersen 2008; Raith et al. 2013; Wilding 1989), Southern Arabia (Sedov 2010b, pp. 465-466) and India (Tomber 2009, p. 48). The content of these amphorae has not been established, but garum (Parker 1998, pp. 390-391), dates, and wine and a variety of agricultural products from the hinterland have been suggested (Parker 1998, pp. 390-391, 2009, p. 83; Peacock 2007, pp. 103-104).

Pre-Islamic ports along the Arabian coast of the Red Sea are still largely not documented. Most scholars suggest the Nabataean port of Leuke Kome was located at Aynuna (Graf 2000), near the entrance to the Gulf of Aqaba, where remains of a Nabataean settlement are documented (Ingraham et al. 1981, pp. 76-78); others have favored al-Wajh, $250 \mathrm{~km}$ farther south, on topographical and literary grounds (Nappo 2010). In the Farasan Islands, off the coast of southern Saudi Arabia, the sensational find of two Latin inscriptions documenting Roman military presence in the second century AD (Phillips et al. 2004; Villeneuve 2004, 2005-2006, 2007) has been followed by surveys by the University of Exeter MARES Project (Cooper and Zazzaro 2012) that promise to shed more light on the pre-Islamic archaeology of these strategically situated islands.

\section{The archaeology of trade in the western Indian Ocean}

Several developments are possible as a result of the profusion of available sites, data, and studies described above. The archaeology of Indian Ocean trade is clearly freeing itself from the constraints of a past as a discipline primarily of historical archaeology. Most of the recently documented sites are not mentioned in the classical or other literary sources, are not possible to positively identify with places recorded there, or have a much longer period of occupation and activity than is indicated in the literary material. Moreover, the chronological horizon, which was long restricted to the first 
two centuries $\mathrm{AD}$, has come to encompass the late first millennium $\mathrm{BC}$ and the entire first millennium AD. The great volume of recent finds and the relative prosperity of port sites from the third to the seventh century AD show that old analyses of the fluctuations of Indian Ocean trade, based on economic patterns in the Mediterranean, need to be reconsidered. Finally, although material of Mediterranean origin continues to dominate the record of imported pottery at most Indian Ocean sites, the presence of ceramics from Arabia, East Africa (Aksum), South Arabia, Mesopotamia, and India at sites across the western Indian Ocean, along with textiles, archaeobotanical, and zooarchaeological material, gives a much more varied and comprehensive image of commodities and carriers in the monsoon exchange.

Regardless of the surge in projects, fieldwork, and publication over the last two decades, there is still plenty of work to do. None of the sites discussed above has exhausted their potential for surveys and excavations, and a number of major ports known from literary sources and the multitude of smaller maritime communities remain unidentified. The archaeology of the Arabian Red Sea coast and the African coast south of Egypt in the first millennium AD (with the notable exception of Adulis) is still virtually unknown, and many known sites in India, Arabia, and the Persian Gulf have been subject to little more than registration.

In addition to the results from research on specific sites and regions, several fields of study with relevance across the region also have benefited from recent work. Wreck sites discovered in the western Indian Ocean, the Persian Gulf, and the Red Sea have thus far not yielded identifiable remains of ships. The remains of Mediterranean-style fittings along with sails woven from Indian cotton (Blue 2009; Blue et al. 2011; Handley 2011; Wild and Wild 2001, 2007) and both cedar from Lebanon and teak from India fixed in traditional Mediterranean mortise and tenon technique (Sidebotham 2011, pp. 203-205; Sidebotham and Wendrich 2007, p. 290; Sidebotham and Zych 2010, pp. 19-20) that have been recovered at Berenike and Myos Hormos indicate a complex situation. Discussions on technology and navigation also continue to concentrate on comparative evidence. Mediterranean and later-period Indian Ocean ships have been used to tentatively discuss the performance of ancient ships (Pomey 2012; Varadarajan 1995; Whitewright 2007a, b). The monsoons have not changed significantly since antiquity (Gupta et al. 2003), and modern pilot guides and navigational charts, along with historical descriptions, can be used to reconstruct seasonal sailing patterns (Beresford 2013; Casson 1989, pp. 283-291; Facey 2004; Seland 2008, 2011).

Although ethnicity-loosely defined as perceived common ancestry combined with boundary maintenance (Barth 1969; Brubaker 2005, pp. 5-7)—was clearly a relevant category to people in the ancient world, it remains a challenge to identify and trace in the archaeological record ( $\mathrm{Hu}$ 2013). Several Indian Ocean sites, however, have yielded evidence on the cultural affiliation and geographical origin of inhabitants and visitors. The ceramic record from Arikamedu and other sites in southern India has been cautiously interpreted in favor of the resident foreign community envisioned by Wheeler (Tomber 2008, pp. 147-152; Will 2004). Cooking pots of Indian origin at Khor Rori in Oman could indicate long-term visits by sailors from the subcontinent (Pavan and Schenk 2012; Sedov and Benvenuti 2002; Yule 1993, p. 81); related finds from Myos Hormos (Tomber 2011) and 
Berenike (Sidebotham 2011, p. 75) invite similar conclusions. Thomas (2012), using proxies such as diet, occupation, and tableware, has argued that groups of different origin resided in different quarters of Egyptian Red Sea ports. Language is another potentially useful though indirect proxy. Berenike and Myos Hormos have yielded written evidence in South Arabian and Tamil-Brahmi script (Sidebotham 2011, p. 75; Tomber 2011). The Latin inscriptions from the Farasans, and possibly also the Greek dedication from Qana (Bowersock 1993), are indications of outward mobility from Egyptian ports. Drawing on epigraphic material in Prakrit, Sanskrit, Old Sinhalese, and Tamil, all in Brahmi script, from sites in peninsular India, Ray (2006, p. 121) has identified three language groups involved in overlapping trading networks. Most spectacular, of course, is the evidence from Hoq, Socotra, where worshipers utilizing Greek, Aramaic, South Arabian, Ethiopic, and several Indic languages sought out the same sanctuary (Dridi 2002; Robin and Gorea 2002; Strauch 2012; Strauch and Bukharin 2004).

On a related note, there is increasing evidence of religion as a potential group marker. In addition to the sanctuary at Socotra, several temples and a church have been excavated at Berenike (Sidebotham 2011, pp. 81-85), temples at Qana and Khor Rori (Pavan and Sedov 2008; Sedov 2005), and a synagogue at Qana (Sedov 2010a). Attempts also have been made at tracing the connections between trade and Christianity in the later part of the pre-Islamic period (Seland 2012b; Tomber 2007a). The combined findings of these studies underline the multicultural nature of ancient Indian Ocean trade. Merchants and sailors from all coasts of the western Indian Ocean took active part. The seasonality of the monsoons implied prolonged stays in foreign ports, where visiting merchants would interact with local inhabitants. Business, personal circumstances, slave trade (Walz and Brandt 2006), and shipwrecks would cause people to stay abroad permanently or for long periods of time, and it seems safe to assume that all major ports taking part in Indian Ocean trade also would be home to a foreign diaspora. In that respect, Wheeler's (1955) Rome beyond the Imperial Frontiers was perhaps not so far off target after all, although the narrative it contained was blatantly one-sided.

\section{The western Indian Ocean and the archaeology of exchange}

Trade is a basic human activity and a principal agent of change. Being characterized by the movement and exchange of material objects, it is a longstanding preoccupation of archaeological research (Oka and Kusimba 2008). Arguably, the western Indian Ocean was the single most important arena of commercial integration between different parts of the Old World. Nevertheless, data from the region have rarely been invoked in general discussions of ancient trade, and with the notable exception of Beaujard's $(2005,2012)$ analyses of Indian Ocean history in light of world-systems theory, few archaeologists working with the region have drawn explicitly on models of early exchange developed in other settings. This is all the more striking as the Indian Ocean plays a major role in the discourse on longdistance trade in later periods. Reasons for this are not clear, but as outlined in the Introduction, the relative lack of interest in long-distance trade, which prevailed 
until recently in post-Finley classical studies, and the legitimate program of building national archaeologies and historiographies in recently independent Indian Ocean countries might have played a role. Also, with only limited previous research on which to draw, archaeologists have understandably concentrated on establishing chronologies, typologies, and connections rather than on the potential theoretical implications of their work. Concluding this review, I point to some closely interrelated areas where I believe the archaeology of the western Indian Ocean has a contribution to make to archaeologists interested in trade and exchange in other settings, as well as some theoretical perspectives that might enhance our understanding of Indian Ocean commerce.

My first point is in regard to the scale and nature of trade. Scholars working with the classical world and inspired by Finley, as well as archaeologists and economic anthropologists following Polanyi, have tended to downplay the scale and significance of long-distance trade in the ancient world. As long as little archaeological evidence was available, the handful of literary sources referring to the large number of ships sailing for India from Egypt every year (Strabo Geography 2.5.12, 17.1.45, see Jones 2001) and the drain of currency inflicted on the Roman Empire as a result of trade with Arabia and India (Pliny Natural History 6.26, 12.41, see Rackham 1997-2001) were easily dismissed as overstatements by members of a Roman literary elite, writing with no real knowledge of what was happening on the ground. Such figures cannot indeed be taken at face value. The collected volume of imported pottery yet recovered from western Indian Ocean settings would easily fit within a single ancient trading vessel, and we will never be able to quantify the volume of trade. Nevertheless, there is no doubt anymore that Indian Ocean commerce was large scale, long-lived, and extensive in terms of the places, vessels, people, and economic assets involved. It also is clear that Indian Ocean trade was not limited to luxuries but involved subsistence goods such as foodstuffs, inexpensive textiles, spices, and aromatics consumed by large numbers of people for their everyday religious, culinary, and medicinal needs. This has significant implications: If Indian Ocean trade was important to the people taking part in it, then it had an impact on the lives of people living all over the ancient world, from the Mediterranean to Africa, India, and arguably even China.

In a seminal paper almost four decades ago, Renfrew (1975) described trade as "action at a distance," thereby underlining the social dimension of exchange. Much work remains with regard to understanding the role of trade and the social significance of imported commodities in ancient Indian Ocean societies. Elsewhere I have argued that imported prestige goods seem to have acted as important status markers, which local elites on the Indian Ocean rim could apply in political processes (Seland 2010). That Indian Ocean trade affected the lives and agendas of elites as well as ordinary people on the Indian Ocean rim highlights their independent agency. Maritime communities in the western Indian Ocean did not engage in order to satisfy distant imperial demand for luxuries but for reasons entirely of their own. On a community level, the processes of change resulting from trade can be approached in terms of diffusion, hybridization, creolization, and arguably even proto-globalization of material culture and ideas. On a polity level, such processes have a clear potential for interpretation within a second important 
paradigm introduced by Renfrew (1986), namely, that of "peer-polity interaction." The large volume of combined trade in prestige and subsistence goods as well as bullion also would have represented an attractive source of revenue to rulers on the Indian Ocean rim, evident, for instance, in the special $25 \%$ tax called the tetarte ("fourth") levied by Roman authorities on Indian Ocean trade, a rate unparalleled elsewhere in the ancient world. Nevertheless, early Indian Ocean polities have thus far been all but absent from key debates on the emergence of complex societies (Feinman and Marcus 1998; Yoffee 2005), and this is a field where Indian Ocean archaeology has much to offer as well as much to learn.

As a second point, Indian Ocean archaeology, especially by means of epigraphic finds and ceramic studies but also increasingly by way of archaeobotany, has highlighted the great degree of connectivity and mobility in the ancient world. In their seminal volume, The Corrupting Sea, Horden and Purcell (2000) draw a picture of the Mediterranean world as consisting of microregions connected by innumerable everyday ties, shortdistance contacts between neighboring societies taking prevalence over long-distance travel and exchange. Such ties were without doubt of great significance also in the western Indian Ocean world, but nevertheless I would argue that Horden and Purcell's model of Mediterranean connectivity does not transfer well to the region. Larger distances, significant ecological differences between microregions connected by the sea, scattered habitation along many coasts, and the regularity of the monsoon system caused a lot of people to spend significant portions of their lives in locations far from the place they were born. This did not include only merchants and sailors but also artisans, guards, mercenaries, and adventurers-rich and poor, free and slave.

These people would have brought with them culinary habits (e.g., crops), technologies (shipbuilding, glassmaking, weaving traditions), and ideas (symbols and religions), making the ocean and its coasts an area of cultural integration and diffusion. The western Indian Ocean is thus well suited for studies of cross-cultural encounters and interaction, including processes resembling those of modern globalization. In that respect Braudel's (1966) La Méditerranée and Kristiansen's (2000) Europe before History might actually be more suitable models for macrolevel interpretations of ancient Indian Ocean trade.

Studying connectivity by archeological proxies is challenging. That objects produced in a certain region, e.g., India, are recovered in a different setting, e.g., the Persian Gulf, give limited insight into how they were moved. Patterns of movement determined by seasonal variation and climatic conditions as documented in ethnographic accounts might be one place to start. A different approach is offered by the recent resurgence of network analysis in archaeology (Brughmans 2010, 2013; Knappett 2011, 2013). While network analyses of land-based flows of commodities are hampered by the fact that people are known to often choose an apparently suboptimal route of travel for reasons of safety or transaction costs (Seland 2012a), maritime networks can more readily be reconstructed based on concepts such as centrality, gravity, and proximal point analysis (Knappett et al. 2008; Rivers et al. 2013). Network analysis might be a way to address long-standing questions in western Indian archaeology on the relationship between long-distance cross-ocean navigation and short-distance coastal cabotage. 
This anticipates my final point, namely, that Indian Ocean archaeology has great potential to shed light on the human side of ancient trade. How did Indian Ocean societies cope with the organizational challenges of establishing trust, social cohesion, and security in situations of asymmetrical power, imperfect information, and divergent institutional frameworks? Curtin's (1984) much used model of the trading diasporagroups of merchants settled on foreign ground, acting as brokers between home and guest culture - at first sight seems well suited to the setting of the monsoon trade. Recently, however, it has come under criticism with regard to early modern trade on the grounds that it presupposes the existence of a homeland that is lacking in the Jewish, Armenian, and Islamic networks operating in the same region in later history (Aslanian 2011). Questions of the ethnic identity of ancient Indian Ocean merchants have been contentious but have over time led to a nuanced understanding of the agents involved. Recent sociological and anthropological scholarship, however, is rapidly moving beyond ethnicity as a prime identity marker and also tries to address other kinds of "groupness" (Brubaker 2005, 2009). Indian Ocean archaeology could benefit from and contribute to this theoretical discourse and thus partly escape the problem of connecting pots with people. Merchant communities in the western Indian Ocean arguably also seem to have organized according to other variables in addition to ethnicity, including language (Ray 2006), geographical origin, and religion (Seland 2013). Comparative studies of material from the fair number of contemporary port sites now available might offer insights that will have interest far beyond the coasts of the Indian Ocean.

In summary, while recent studies have led to major breakthroughs in our understanding of the chronology as well as the extent and substance of ancient Indian Ocean exchange, there is clearly a great potential for interdisciplinary, cross-period, and comparative studies in the field, which has thus far been only partially realized. Most of the publications cited above are products of solid regional traditions of archaeology. This will and should remain so, but arguably many sites on the Indian Ocean rim make equal or, in some cases, even more sense when approached from a maritime perspective compared with a hinterland point of view. The research described above makes it clear that well-worn labels such as "Indo-Roman trade" or "Rome's trade with the East" allow us to grasp only a fraction of what ancient Indian Ocean exchange was about. The challenge still remains, however, of contextualizing evidence from regional settings against an Indian Ocean backdrop and bringing data from Indian Ocean archaeology into dialogue with wider debates on the nature, mechanisms, and organization of premodern trade within archaeology, anthropology, and history.

Acknowledgments A number of colleagues have generously provided access to publications and information on results of ongoing work and research projects. Thanks are due to Dionisius A. Agius, Marie-Françoise Boussac, Deborah Carlson, Felix Chami, Kristoffer Damgaard, Sunil Gupta, Randi Håland, Derek Kennet, Himanshu P. Ray, Alexander V. Sedov, St John Simpson, Steven E. Sidebotham, Roberta Tomber, Jean-Baptiste Yon, Paul Yule, Jonathan R. Walz, and Chiara Zazzaro. Senior librarian Kari Normo, Bergen University Library, provided invaluable help in getting swift access to publications not at hand in Bergen. Finally, I am grateful to the editors and anonymous peer reviewers of JARE for their constructive and specific advice and criticism.

Open Access This article is distributed under the terms of the Creative Commons Attribution License which permits any use, distribution, and reproduction in any medium, provided the original author(s) and the source are credited. 


\section{References cited}

Albright, F. P. (1982). The American Archaeological Expedition in Dhofar, Oman, AFSM, Washington, DC.

Andersen, S. F. (2007). The Tylos Period Burials in Bahrain, Aarhus University Press, Aarhus.

Anfray, F. (1974). Deux villes Axoumites; Adoulis et Matara. In IV Congresso Internationale di Studi Etiopici, Accademia Nazionale Dei Lincei, Rome, pp. 745-766.

Aslanian, S. D. (2011). From the Indian Ocean to the Mediterranean: The Global Trade Networks of Armenian Merchants from New Julfa, University of California Press, Berkeley.

Avanzini, A. (ed.) (2002). Khor Rori Report I, Arabia Antica, Edizioni Plus, Pisa.

Avanzini, A. (2008). Khor Rori Report 2: A Port in Arabia between Rome and the Indian Ocean (3rd C. $B C-5$ th C. $A D$ ), Edizioni Plus, Rome.

Avanzini, A., and Sedov, A. V. (2005). The stratigraphy of Sumhuram: New evidence. Proceedings of the Seminar for Arabian Studies 35: 11-17.

Bagnall, R. S., Helms, C., and Verhoogt, A. M. (2000). Documents from Berenike I: Greek Ostraka from the 1996-1998 Seasons, Association Egyptologique Reine Élisabeth, Brussels.

Bagnall, R. S., Helms, C., and Verhoogt, A. M. (2005). Documents from Berenike II: Texts from the 1999 2001 Seasons, Association Egyptologique Reine Élisabeth, Brussels.

Bandaranayake, S. (ed.) (1990). Sri-Lanka and the Silk Road of the Sea, UNESCO, Colombo.

Barth, F. (1969). Introduction. In Barth, F. (ed.), Ethnic Groups and Boundaries: The Social Organization of Cultural Difference, Universitetsforlaget, Oslo, pp. 9-38.

Beaujard, P. (2005). The Indian Ocean in Eurasian and African world-systems before the sixteenth century. Journal of World History 16: 411-465.

Beaujard, P. (2011). The first migrants to Madagascar and their introduction of plants: Linguistic and ethnological evidence. Azania: Archaeological Research in Africa 46: 169-189.

Beaujard, P. (2012). Les mondes de l'Océan Indien 1: De la formation de l'état au premier système-monde afro-eurasien (4e millénaire av. J.-C. - 6e siècle apr. J.-C.), Colin, Paris.

Begley, V. (1983). Arikamedu reconsidered. American Journal of Archaeology 80: 461-481.

Begley, V. (1988). Rouletted ware at Arikamedu: A new approach. American Journal of Archaeology 92: 427-440.

Begley, V. (1993). New investigations at the port of Arikamedu. Journal of Roman Archaeology 6: 93-108.

Begley, V., and Tomber, R. (1999). Indian pottery sherds. In Sidebotham, S. E., and Wendrich, W. Z. (eds.), Berenike 1997: Report of the 1997 Excavations at Berenike and the Survey of the Egyptian Eastern Desert, including Excavations at Shenshef, Universiteit Leiden, Leiden, pp. 161-182.

Begley, V., Francis, P. J., Mahadevan, I., Raman, K. V., Sidebotham, S. E., Slane, K. W., and Will, E. L. (1996). The Ancient Port of Arikamedu, École Francaise d'Extrême-Orient, Paris.

Begley, V., Francis, P., Jr., Karashima, N., Raman, K. V., Sidebotham, S. E., and Will, E. L. (2004). The Ancient Port of Arikamedu. New Excavations and Researches, 1989-1992 Volume Two, École Française d'Extrême-Orient, Paris.

Benoist, A., Mouton, M., and Schiettecatte, J. (2003). The artefacts from the fort at Mleiha: Distribution, origins, trade and dating. Proceedings of the Seminar for Arabian Studies 33: 59-76.

Bent, J. T., and Bent, M. T. (1900). Southern Arabia, Smith, Elder \& Co., London.

Beresford, J. (2013). The Ancient Sailing Season, Brill, Boston.

Blue, L. (2007). Locating the harbour: Myos Hormos/Quseir al-Qadim: A Roman and Islamic port on the Red Sea coast of Egypt. International Journal of Nautical Archaeology 36: 265-281.

Blue, L. (2009). Boats, routes and sailing conditions of Indo-Roman Trade. In Tomber, R., Blue, L., and Abraham, S. (eds.), Migration, Trade and Peoples, Part 1: Indian Ocean Commerce and the Archaeology of Western India, British Association for South Asian Studies, The British Academy, London, pp. 3-13.

Blue, L. (2011). 4: The amphora wharf: The context and construction of Roman amphora installations. In Blue, L., and Peacock, D. (eds.), Myos Hormos-Quseir al-Qadim. Roman and Islamic Ports on the Red Sea, Volume 2: Finds from the Excavations 1999-2003, BAR International Series 2286, Archaeopress, Oxford, pp. 35-42.

Blue, L., Whitewright, J., and Thomas, R. (2011). 15: Ships and ships' fittings. In Blue, L., and Peacock, D. (eds.), Myos Hormos-Quseir al-Qadim. Roman and Islamic Ports on the Red Sea, Volume 2: 
Finds from the Excavations 1999-2003, BAR International Series 2286, Archaeopress, Oxford, pp. 179-209.

Boivin, N., Blench, R., and Fuller, D. (2010). Archaeological, linguistic and historical sources on ancient seafaring: A multidisciplinary approach to the study of early maritime contact and exchange in the Arabian Peninsula. In Petraglia, M. D., and Rose, J. I. (eds.), The Evolution of Human Populations in Arabia, Springer, Dordrecht, pp. 251-278.

Boivin, N., Fuller, D. Q., and Crowther, A. (2012). Old World globalization and the Columbian exchange: Comparison and contrast. World Archaeology 44: 452-469.

Bopearachchi, O. (1992). Le commerce maritime entre Rome et Sri Lanka d'après les donnes numismatiques. Revue des Ètudes Anciennes 94: 107-121.

Bopearachchi, O. (1998). Archaeological evidence on changing patterns of international trade relations of ancient Sri Lanka. In Bopearachchi, O., and Weerakkody, D. P. (eds.), Origin, Evolution and Circulation of Foreign Coins in the Indian Ocean, Manohar, New Delhi, pp. 133-178.

Bowersock, G. W. (1993). The new Greek Inscription from South Yemen. In Langdon, J. S., Reinert, S. W., Allen, J. S., and Ioannides, C. P. (eds.), TO EムAHNIKON [To Hellenikon]: Studies in Honor of Speros Vryonis, Jr., Aristide D. Caratzas, New Rochelle, NY, pp. 3-8.

Braudel, F. (1966). La Méditerranée et le monde méditerranéen à l'époque de Philippe II, A. Colin, Paris.

Breton, J.-F. (1999). Arabia Felix from the Time of the Queen of Sheba, University of Notre Dame Press, Notre Dame, IN.

Brubaker, R. (2005). The 'diaspora' diaspora. Ethnic and Racial Studies 28: 1-19.

Brubaker, R. (2009). Ethnicity, race, and nationalism. Annual Review of Sociology 35: 21-42.

Brughmans, T. (2010). Connecting the dots: Towards archaeological network analysis. Oxford Journal of Archaeology 29: 277-303.

Brughmans, T. (2013). Thinking through networks: A review of formal network methods in archaeology. Journal of Archaeological Method and Theory 20: 623-662.

Bukharin, M. D. (2011). The notion $\tau$ ò $\pi \dot{\varepsilon} \rho \alpha \varsigma \tau \tilde{\eta} \varsigma \alpha v \alpha \kappa o \mu t \delta \tilde{\eta} \varsigma$ and the location of Ptolemais of the Hunts in the Periplus of the Erythraean Sea. Arabian Archaeology and Epigraphy 22: 219-231.

Callot, O., Gachet-Bizollon, J., and Salles, J.-F. (2005). Ikaros, de la conquête d'Alexandre au Ier siècle après J.-C. In Galliano, G. (ed.), L’île de Failaka: Archéologie du Koweït, Somogy and Musée des Beaux-Arts, Lyon, pp. 63-93.

Cappers, R. T. (2006). Roman Foodprints at Berenike: Archaeobotanical Evidence of Subsistence and Trade in the Eastern Desert of Egypt, University of California, Los Angeles.

Carlson, D. (2010). INA in Sri Lanka: Pearl of the Indian Ocean. INA Annual 2010: 89-95.

Carswell, J. (1991). The port of Mantai, Sri Lanka. In Begley, V., and De Puma, R. D. (eds.), Rome and India, the Ancient Sea Trade, University of Wisconsin Press, Madison, pp. 197-203.

Carswell, J., Deraniyagala, S. U., and Graham, A. (2013). Mantai: City by the Sea, Linden Soft, Aichwald.

Casal, J. M. (1949). Fouilles de Virampatnam-Arikamedu, Imprimerie Nationale, Paris.

Casal, J. M., and Casal, G. (1956). Site urbain et sites funéraires des environs de Pondichéry Virampatnam, Mouttrapaléon, Souttoukèny, Presses Universitaires de France, Paris.

Casson, L. (1989). The Periplus Maris Erythraei, Princeton University Press, Princeton, NJ.

Casson, L. (1993). Ptolemy II and the hunting of African elephants. Transactions of the American Philological Association 123: 247-260.

Chami, F. A. (1999). Roman beads from the Rufiji Delta, Tanzania: First incontrovertible archaeological link with the Periplus. Current Anthropology 40: 237-241.

Chami, F. A. (2004). Graeco-Roman documents about Azania: A new look at some controversial issues. In Oestigaard, T., Anfinset, N., and Saetersdal, T. (eds.), Combining the Past and the Present: Archaeological Perspectives on Society, BAR International Series 1210, Archeopress, Oxford, pp. 137-141.

Chami, F. A. (2005). The ancient western Indian Ocean world market: 600-300 BC. Journal of Indian Ocean Archaeology 2: 1-7.

Chami, F. A., and Msemwa, P. J. (1997). A new look at culture and trade on the Azanian coast. Current Anthropology 38: 673-677.

Charlesworth, M. P. (1926). Trade Routes and the Commerce of the Roman Empire, Cambridge University Press, Cambridge.

Cherian, P. J. (2011). Kerala Council for Historical Research annual report 2010-2011. Kerala Council for Historical Research, Thiruvananthapuram. 
Cherian, P. J., Selvakumar, V., and Shajan, K. P. (2007). The Muziris Heritage Project excavations at Pattanam, 2007. Journal of Indian Ocean Archaeology 4: 1-10.

Cherian, P. J., Ravi-Prashad, G. V., Dutta, K., Ray, D. K., Selvakumar, V., and Shajan, D. K. (2009). Chronology of Pattanam: A multi-cultural port site on the Malabar coast. Current Science 97: 236240.

Cheung, C., DeVantier, L., and Damme, K. v. (2006). Socotra : A Natural History of the Islands and Their People, Odyssey, Hong Kong.

Chittick, N. (1969). An archaeological reconnaissance of the southern Somali coast. Azania 4: 115-130.

Chittick, N. (1976). An archaeological reconnaissance in the Horn: The British-Somali Expedition, 1975. Azania 11: 117-133.

Chittick, N. (1979). Early ports in the Horn of Africa. The International Journal of Nautical Archaeology and Underwater Exploration 8: 273-277.

Coningham, R. (2002). Beyond and before the imperial frontiers: Early historic Sri Lanka and the origins of Indian Ocean trade. Man and Environment 27: 99-108.

Coningham, R. (2006). Anuradhapura: The British-Sri Lankan Excavations at Anuradhapura Salgaha Watta 2, Volume 2: The Artefacts, BAR International Series 1508, Archaeopress, Oxford.

Coningham, R., and Raymond, A. F. (1999). Anuradhapura: The British-Sri Lankan Excavations at Anuradhapura Salagha Watta 2, Volume 1, BAR International Series 824, Archaeopress, Oxford.

Coningham, R., Allchin, F. R., Batt, C. M., and Lucy, D. (1996). Passage to India? Anuradhapura and the early use of the Brahmi script. Cambridge Archaeological Journal 6: 73-97.

Cooper, J. P., and Zazzaro, C. (2012). A stone anchor from the Farasan Islands, Saudi Arabia. International Journal of Nautical Archaeology 41: 407-411.

Crowfoot, J. W. (1911). Some Red Sea ports in the Anglo-Egyptian Sudan. The Geographical Journal 37: 523-550.

Curtin, P. D. (1984). Cross-Cultural Trade in World History, Cambridge University Press, Cambridge.

Damgaard, K. (2009). A Palestinian Red Sea port on the Egyptian road to Arabia: Early Islamic Aqaba and its many hinterlands. In Blue, L., Cooper, J., Thomas, R., and Whitewright, J. (eds.), Connected Hinterlands: Proceedings of Red Sea Project IV Held at the University of Southampton, September 2008, BAR International Series 2052, Archaeopress, Oxford, pp. 85-98.

Daryaee, T. (2009). The Persian Gulf in late antiquity: The Sasanian era (200-700 CE). In Potter, L. G. (ed.), The Persian Gulf in History, Macmillan, New York, pp. 57-70.

De Maigret, A. (2002). Arabia Felix: An Exploration of the Archaeological History of Yemen, Stacy International, London.

Decker, M. (2010). Settlement and trade in the Red Sea in late antiquity: An archeological perspective. Ancient West and East 9: 193-220.

Della Valle, P., Roe, T., and Havers, G. (1665). The Travels of Sig. Pietro della Valle, a Noble Roman, into East-India and Arabia Deserta, Henry Herringman, London.

Delplace, C. (2003). Palmyre et l'Inde (à propos de l'inscription Inv. X, 88). Collection Latomus 270: $158-167$.

Doe, B. (1961). Husn al-Ghurab and the site of Qana. Le Museon: Revue d'Etudes Orientales 74: 191-198.

Doe, D. B. (1970). Socotra: An Archaeological Reconnaissance in 1967, Field Research Projects, Coconut Grove, FL.

Dridi, H. (2002). Indiens et proche-orientaux dans une grotte de Suquțāa (Yemen). Journal Asiatique 290: 565-610.

Earle, T. K., and Ericson, J. E. (1977). Exchange Systems in Prehistory, Academic Press, New York.

Facey, W. (2004). The Red Sea: The wind regime and location of ports. In Lunde, P., and Porter, A. (eds.), Trade and Travel in the Red Sea Region: Proceedings of the Red Sea Project I Held in the British Museum, October 2002, BAR International Series 1269, Archaeopress, Oxford, pp. 7-17.

Feinman, G. M., and Marcus, J. (eds.) (1998). Archaic States, School of American Research Press, Santa $\mathrm{Fe}, \mathrm{NM}$.

Finley, M. I. (1973). The Ancient Economy, Chatto and Windus, London.

Ford, L. A., Pollard, A. M., Coningham, R. A., and Stern, B. (2005). A geochemical investigation of the origin of rouletted and other related South Asian fine wares. Antiquity 79: 909-920.

Francis, P., Jr. (1991). Beadmaking at Arikamedu and beyond. World Archaeology 23: 28-43.

Fuller, D. Q., Boivin, N., Hoogervorst, T., and Allaby, R. (2011). Across the Indian Ocean: The prehistoric movement of plants and animals. Antiquity 85: 544-558. 
Gaur, A. S., Sundaresh, and Tripati, S. (2006). Evidence for Indo-Roman trade from Bet Dwarka Waters, west coast of India. The International Journal of Nautical Archaeology 35: 117-127.

Gawlikowski, M. (1994). Palmyra as a trading centre. Iraq 56: 27-33.

Ghirshman, R. (1958). L'île de Kharg dans le golfe Persique. Comptes-Rendus des Séances de l'Académie des Inscriptions et Belles-Lettres 102: 261-269.

Glover, I. (2002). West Asian Sassanian-Islamic ceramics in the Indian Ocean, South, Southeast and East Asia. Man and Environment 27: 165-177.

Graf, D. F. (2000). Map 83 Nabataea Meridionalis. In Talbert, R. J. (ed.), Barrington Atlas of the Greek and Roman World: Map-By-Map Directory, Volume 2, Princeton University Press, Princeton, NJ, pp. $1192-1198$.

Gupta, A., Anderson, D. M., and Overpeck, J. M. (2003). Abrupt changes in the Asian southwest monsoon during the Holocene and their links to the North Atlantic Ocean. Nature 421: 354-357.

Gupta, S. (1996). Beyond Arikamedu: Macro stratigraphy of the Iron Age-Early Historic transition and Roman contact in South India. Puratattva 25: 50-51.

Gupta, S. (1998). Nevasa: A type-site for the study of Indo-Roman trade in western India. South Asian Studies 14: 87-102.

Gupta, S. (2005). The Bay of Bengal interaction sphere (1000 BC-AD 500). Bulletin of the Indo-Pacific Prehistory Association 25: 21-30.

Gupta, S., Williams, D., and Peacock, D. (2001). Dressel 2-4 amphorae and Roman trade with India: The evidence from Nevasa. South Asian Studies 17: 7-18.

Gupta, S. P., Gupta, S., Garge, T., Pandey, R., Geetali, A., and Gupta, S. (2004). On the fast track of the Periplus: Excavations at Kamrej, 2003. Journal of Indian Ocean Archaeology 1: 9-33.

Haerinck, E. (1998). International contacts in the southern Persian Gulf in the late 1st century BC/1st century AD: Numismatic evidence from Ed-Dur (Emirate of Umm Al-Qaiwain, UAE). Iranica Antiqua 33: 273-302.

Haerinck, E. (2001). Excavations at Ed-Dur (Umm al-Qaiwain, United Arab Emirates) 2: The Tombs, Peeters, Leuven.

Haerinck, E. (2011). A Temple of the Sun-God Shamash and other Occupational Remains at Ed-Dur (Emirate of Umm Al-Qaiwain, UAE), Peeters, Leuven.

Håland, R. (2013). Meroitic iron working in a global Indian Ocean context. In Humphris, J., and Rehren, T. (eds.), World of Iron, Archetype Publications, London, pp. 146-155.

Handley, F. (2011). 22: The textiles: A preliminary report. In Blue, L., and Peacock, D. (eds.), Myos Hormos-Quseir al-Qadim. Roman and Islamic Ports on the Red Sea, Volume 2: Finds from the Excavations 1999-2003, BAR International Series 2286, Archaeopress, Oxford, pp. 321-333.

Hannestad, L. (1983). The Hellenistic Pottery from Failaka: With a Survey of Hellenistic Pottery in the Near East, Jysk Arkæologisk Selskab, Aarhus.

Helm, R., Crowther, A., Shipton, C., Tengeza, A., Fuller, D., and Boivin, N. (2012). Exploring agriculture, interaction and trade on the eastern African littoral: preliminary results from Kenya. Azania 47: 39-63.

Horden, P., and Purcell, N. (2000). The Corrupting Sea: A Study of Mediterranean History, Blackwell, Oxford.

Horton, M., and Middleton, J. (2000). The Swahili: The Social Landscape of a Mercantile Society, Blackwell, Oxford.

Howgego, C. J., and Potts, D. T. (1992). Greek and Roman coins from Eastern Arabia. Arabian Archaeology and Epigraphy 3: 183-189.

Hu, D. (2013). Approaches to the archaeology of ethnogenesis: Past and emergent perspectives. Journal of Archaeological Research 21: 1-32.

Ingraham, M. L., Johnson, T. D., Rihani, B., and Shatla, I. (1981). Preliminary report on a reconnaissance survey of the Northwestern Province (with a note on a brief survey of the Northern Province). Atlal 5: $65-97$.

Jasim, S. A. (2006). Trade centres and commercial routes in the Arabian Gulf: Post-Hellenistic discoveries at Dibba, Sharjah, United Arab Emirates. Arabian Archaeology and Epigraphy 17: 214-237.

Jeppesen, K. (1989). The Sacred Enclosure in the Early Hellenistic Period, Jysk Archaeologisk Selskab, Aarhus.

Jones, H. L. (2001). The Geography of Strabo with an English Translation, Harvard University Press, Cambridge, MA. 
Jouveau-Dubreuil, G. (1940). IV. Les ruines romaines de Pondichéry. Bulletin de l'Ecole Française d'Extrême-Orient 40: 448-450.

Juma, A. (2004). Unguja Ukuu on Zanzibar: An Archaeological Study of Early Urbanism, Uppsala University, Uppsala.

Kennedy, D. (2011). The "Works of the Old Men" in Arabia: Remote sensing in interior Arabia. Journal of Archaeological Science 38: 3185-3203.

Kennedy, D., and Bishop, M. C. (2011). Google Earth and the archaeology of Saudi Arabia: A case study from the Jeddah area. Journal of Archaeological Science 38: 1284-1293.

Kennet, D. (2004). Sasanian and Islamic Pottery from Ras al-Khaimah: Classification, Chronology, and Analysis of Trade in the Western Indian Ocean, BAR International Series 1248, Archaeopress, Oxford.

Kennet, D. (2007). The decline of eastern Arabia in the Sasanian period. Arabian Archaeology and Epigraphy 18: 86-122.

Kervran, M. (1998). Indian ceramics in southern Iran and eastern Arabia: Repertory, classification and chronology. In Ray, H. P., and Salles, J.-F. (eds.), Tradition and Archaeology: Early Maritime Contacts in the Indian Ocean, Manohar, New Delhi, pp. 37-58.

Kervran, M., Hiebert, F. T., and Rougeulle, A. (2005). Qal'at al-Bahrain: A Trading and Military Outpost 3rd Millennium $B C-17$ th century $A D$, Brepols, Turnhout.

Knappett, C. (2011). An Archaeology of Interaction: Network Perspectives on Material Culture and Society, Oxford University Press, Oxford.

Knappett, C. (2013). Network Analysis in Archaeology: New Approaches to Regional Interaction, Oxford University Press, Oxford.

Knappett, C., Evans, T., and Rivers, R. (2008). Modelling maritime interaction in the Aegean Bronze Age. Antiquity 82: 1009-1024.

Kristiansen, K. (2000). Europe Before History, Cambridge University Press, Cambridge.

LaViolette, A. (2008). Swahili cosmopolitanism in Africa and the Indian Ocean world, AD 600-1500. Archaeologies 4: 24-49.

Lawler, A. (2012). Diving into the Indian Ocean's past. Science Magazine 337: 288-289.

Magee, P. (2005). Investigating cross-Gulf trade in the Iron Age III period: Chronological and compositional data on Burnished Maroon Slipped Ware (BMSW) in southeastern Arabia and Iran. Arabian Archaeology and Epigraphy 16: 82-92.

Magee, P. (2010). Revisiting Indian Rouletted Ware and the impact of Indian Ocean trade in early historic South Asia. Antiquity 84: 1043-1054.

Mairs, R. (2012). Glassware from Roman Egypt at Begram (Afghanistan) and the Red Sea trade. British Museum Studies in Ancient Egypt and Sudan 18: 61-74.

McCrindle, J. W. (1979). Ancient India as Described in Classical Literature, Oriental Books Reprint Corporation, New Delhi (reprint of the 1901 edition).

Mehendale, S. (2011). Begram catalogue. In Hiebert, F., and Cambon, P. (eds.), Afghanistan: Crossroads of the Ancient World, British Museum Press, London, pp. 162-209.

Menninger, M. (1996). Untersuchungen zu den Gläsern und Gipsabgüssen aus dem Fund von Begram (Afghanistan), Ergon, Würzburg.

Meyer, C. (1992). Glass from Quseir al-Qadim and the Indian Ocean Trade, Oriental Institute, University of Chicago, Chicago.

Mire, S. (2011). The knowledge-centred approach to the Somali cultural emergency and heritage development assistance in Somaliland. African Archaeological Review 28: 71-91.

Mommsen, T. (1904). Römische Geschichte-fünfter Band: die Provinzen von Caesar bis Diocletian, Weidmannsche Buchhandlung, Berlin.

Mouton, M. (2008). La Péninsule d'Oman de la fin de l'Âge du Fer au début de la période sassanide, 250 av.-350 ap. JC, BAR International Series 1776, Archaeopress, Oxford.

Munro-Hay, S. (1989). The British Museum excavations at Adulis, 1868. Antiquaries Journal 69: 43-52.

Munro-Hay, S., Kaczmarczyk, A., and Phillipson, D. W. (1989). Excavations at Aksum: An Account of Research at the Ancient Ethiopian Capital Directed in 1972-4 by the Late Dr Neville Chittick, The British Institute in Eastern Africa, Nairobi.

Nappo, D. (2010). On the location of Leuke Kome. Journal of Roman Archaeology 23: 335-348.

Naumkin, V. V., and Sedov, A. V. (1995). Monuments of Socotra. In Boussac, M.-F., and Salles, J.-F. (eds.), Athens, Aden, Arikamedu: Essays on the Interrelations between India, Arabia and the Eastern Mediterranean, Manohar, New Delhi. 
Niebuhr, C. (1774). Reisebeschreibung nach Arabien und andern umliegenden Ländern, Nicolaus Möller, Kopenhagen.

Oka, R., and Kusimba, C. (2008). The archaeology of trading systems, part 1: Towards a new trade synthesis. Journal of Archaeological Research 16: 339-395.

Paribeni, R. (1907). Richereche nel luogo dell'antica Adulis. Monumenti Antichi, Reale 18: 438-572.

Parker, S. T. (1998). The Roman Aqaba Project. Annual of the Department of Antiquities of Jordan 42: 375-394.

Parker, S. T. (2009). The Roman port of Aila: Economic connections with the Red Sea Littoral. In Blue, L., Cooper, J., Thomas, R., and Whitewright, J. (eds.), Connected Hinterlands: Proceedings of Red Sea Project IV Held at the University of Southampton September 2008, BAR International Series 2052, Archaeopress, Oxford, pp. 79-84.

Pavan, A. (2007). The harbour of Sumhuram: Preliminary notes on the pottery assemblage from new excavations. Journal of Indian Ocean Archaeology 4: 11-17.

Pavan, A., and Schenk, H. (2012). Crossing the Indian Ocean before the Periplus: A comparison of pottery assemblages at the sites of Sumhuram (Oman) and Tissamaharama (Sri Lanka). Arabian Archaeology and Epigraphy 23: 191-202.

Pavan, A., and Sedov, A. V. (2008). Religious architecture in Sumhuram: The extra muros temple. In Avanzini, A. (ed.), Khor Rori Report 2: A Port in Arabia between Rome and the Indian Ocean (3rd C. BC-5th C. AD), L'Erma di Bretshneider, Rome, pp. 261-275.

Peacock, D. (2007). Pottery from the survey. In Peacock, D., and Blue, L. (eds.), The Ancient Red Sea Port of Adulis, Eritrea: Results of the Eritro-British Expedition, 2004-2005, Oxbow, Oxford, pp. 79-108.

Peacock, D. (2011). 7: Glass. In Blue, L., and Peacock, D. (eds.), Myos Hormos-Quseir al-Qadim. Roman and Islamic Ports on the Red Sea, Volume 2: Finds from the Excavations 1999-2003, BAR International Series 2286, Archaeopress, Oxford, pp. 57-78.

Peacock, D., and Blue, L. (eds.) (2006). Myos Hormos-Quseir al-Qadim. Roman and Islamic Ports on the Red Sea, Volume 1: Survey and Excavations 1999-2003, Oxbow, Oxford.

Peacock, D., and Blue, L. (eds.) (2007a). The Ancient Red Sea Port of Adulis, Eritrea: Report of the Eritro-British Expedition, 2004-2005, Oxbow, Oxford.

Peacock, D., and Blue, L. (2007b). Chapter 7: Incense and the port of Adulis. In Peacock, D., Williams, D., and James, S. (eds.), Food for the Gods: New Light on the Ancient Incense Trade, Oxbow, Oxford, pp. 135-140.

Peacock, D., and Blue, L. (eds.) (2011). Myos Hormos-Quseir al-Qadim. Roman and Islamic Ports on the Red Sea, Volume 2: Finds from the excavations 1999-2003, BAR International Series 2286, Archaeopress, Oxford.

Peacock, D., Blue, L., Gebreyesus, Y., and Habtemichael, D. (2004). The Eritreo-British Project at Adulis, interim report 2004, Department of Archaeology, Southampton University, Southampton.

Peacock, D., Williams, D., and James, S. (2007a). Chapter 3: Basalt as ships' ballast and the Roman incense trade. In Peacock, D., Williams, D., and James, S. (eds.), Food for the Gods: New Light on the Ancient Incense Trade, Oxbow, Oxford, pp. 29-70.

Peacock, D., Williams, D., and James, S. (eds.) (2007b). Food for the Gods: New Light on the Ancient Incense Trade, Oxbow, Oxford.

Pedersen, R. K. (2008). The Byzantine-Aksumite period shipwreck at Black Assarca Island, Eritrea. Azania 43: 77-94.

Phillips, C., Villeneuve, F., and Facey, W. (2004). A Latin inscription from South Arabia. Proceedings of the Seminar for Arabian Studies 34: 239-250.

Phillips, W. (1955). Qataban and Sheba: Exploring Ancient Kingdoms on the Biblical Spice Routes of Arabia, Victor Gollancz, London.

Phillipson, D. W. (1998). Ancient Ethiopia: Aksum, Its Antecedents and Successors, British Museum Press, London.

Phillipson, D. W. (2011). Foundations of an African Civilization: Aksum and the Northern Horn, 1000 $B C-1300 A D$, James Currey, Oxford.

Pomey, P. (2012). À propos des navires de la mer Érythrée: découvertes récentes et noveaux aspects de la question Topoi Supplément 11: 111-132.

Potts, D. T. (1991). Nabataean finds from Thaj and Qatif. Arabian Archaeology and Epigraphy 2: $138-144$. 
Potts, D. T. (1997). Roman relations with the Persicus Sinus from the rise of Spasinou Charax (127 BC) to the reign of Shapur II (AD 309-379). In Alcock, S. E. (ed.), The Early Roman Empire in the East, Oxbow, Oxford, pp. 89-107.

Potts, D. T. (2009). The archaeology and early history of the Persian Gulf. In Potter, L. G. (ed.), The Persian Gulf in History, Macmillan, New York, pp. 27-56.

Rackham, H. (1997-2001). Natural History: In Ten Volumes/Pliny (English translation by H. Rackham, W. H. Jones, and D. E. Eichholz), Harvard University Press, Cambridge, MA.

Radowską, J., and Woźniak, M. (2011). Locating the emporium of Berenike: Evidence of geology, geophysical and satellite mapping. In Sidebotham, S. E., and Zych, I. (eds.), Berenike 2008-2009: Report on the Excavations at Berenike, including a Survey in the Eastern Desert, Polish Centre of Mediterranean Archaeology, University of Warsaw, Warsaw, pp. 19-24.

Raith, M., Yule, P., and Damgaard, K. (2013). The view from Zafar: An archaeometric study of the Aqaba pottery complex and its distribution in the 1st millennium CE. Zeitschrift für OrientArchäologie 6: 318-348.

Raschke, M. G. (1978). New studies in Roman commerce with the East. In Temporini, H., and Haase, W. (eds.), Aufstieg und Niedergang der römischen Welt 2.9.2, Walter De Gruyter, Berlin, pp. 604-1361.

Ray, H. P. (1994). The western Indian Ocean and the early maritime links of the Indian subcontinent. Indian Economic and Social History Review 31: 65-88.

Ray, H. P. (2003). The Archaeology of Seafaring in Ancient South Asia, Cambridge University Press, Cambridge.

Ray, H. P. (2006). Inscribed pots, emerging identities: The social milieu of trade. In Olivelle, P. (ed.), Between the Empires: Society in India 300 BCE to 400 CE, Oxford University Press, Oxford, pp. 113-143.

Ray, H. P. (2008). Colonial Archaeology in South Asia: The Legacy of Sir Mortimer Wheeler, Oxford University Press, New Delhi.

Renfrew, C. (1975). Trade as action at a distance: Questions of integration and communication. In Sabloff, J. A., and Lamberg-Karlovsky, C. C. (eds.), Ancient Civilization and Trade, University of New Mexico Press, Albuquerque, pp. 3-60.

Renfrew, C. (1977). Alternative models for exchange and spatial distribution. In Earle, T. K., and Ericson, J. E. (eds.), Exchange Systems in Prehistory, Academic Press, New York, pp. 71-90.

Renfrew, C. (1986). Introduction: Peer polity interaction and socio-political change. In Renfrew, C., and Cherry, J. F. (eds.), Peer Polity Interaction and Socio-Political Change, Cambridge University Press, Cambridge, pp. 1-18.

Rivers, R., Knappett, C., and Evans, T. (2013). What makes a site important? Centrality, gateways and gravity. In Knappett, C. (ed.), Network Analysis in Archaeology: New Approaches to Regional Interaction, Oxford University Press, Oxford, pp. 125-150.

Robin, C., and Gorea, M. (2002). Les vestiges antiques de la grotte de Hôq (Suqutra, Yémen). Comptes Rendus de l'Académie des Inscriptions et Belles-Lettres 146: 409-445.

Rutten, K. (2007). The Roman fine wares of Ed-Dur (Umm al-Qaiwain, UAE) and their distribution in the Persian Gulf and the Indian Ocean. Arabian Archaeology and Epigraphy 18: 8-24.

Sabloff, J. A., and Lamberg-Karlovsky, C. C. (1975). Ancient Civilization and Trade, University of New Mexico Press, Albuquerque.

Salles, J.-F. (ed.) (1988). L'Arabie et ses mers bordières 1: itinéraires et voisinages, GS - Maison d'Orient, Lyon.

Salles, J.-F. (1993). The Periplus of the Erythraean Sea and the Arab-Persian Gulf. In Boussac, M.-F., and Salles, J.-F. (eds.), Athens, Aden, Arikamedu: Essays on the Interrelations between Indian, Arabia and the Eastern Mediterranean, Manohar, New Delhi, pp. 115-146.

Salles, J.-F. (2002). Adaptation culturelle des céramiques hellénistiques? Importation et imitations de produits occidentaux en Inde. In Blondeé, F., Ballet, P., and Salles, J.-F. (eds.), Céramiques hellénistiques et romaines: productions et diffusion en Méditerranée orientale (Chypre, Égypte et côte syro-palestinienne), Maison de l'Orient Méditerranéen-Jean Pouilloux, Lyon, pp. 189-212.

Salles, J.-F. (2012). Le Golfe Persique dans le Pèriple de la mer Érythrée: connaissances fondées et ignorances réelles. Topoi Supplément 11: 293-328.

Salles, J.-F., and Sedov, A. V. (2010). Qani: le port antique du Hadramawt entre la Méditerranée, l'Afrique et l'Inde Fouilles russes 1972, 1985-1989, 1991, 1993-1994, Brepols, Turnhout.

Schenk, H. (2001). The development of pottery at Tissamaharama. In Weisshaar, H.-J., Roth, H., and Wijeyapala, W. (eds.), Ancient Ruhuna: Sri Lankan: German Archaeological Project in the Southern Province, Volume 1, Von Zabern, Mainz, pp. 59-195. 
Schenk, H. (2006). The dating and historical value of Rouletted Ware. Zeitschrift für Archäologie Aussereuropäischer Kulturen 1: 123-152.

Schenk, H. (2007). Parthian glazed pottery from Sri Lanka and the Indian Ocean trade. Zeitschrift für Archäologie Außereuropäischer Kulturen 2: 57-90.

Schiettecatte, J. (2012). L'Arabie du Sud et la mer du IIIe siècle av. au VIe siècle apr. J.-C. Topoi Supplément 11: 237-273.

Schippmann, K. (2001). Ancient South Arabia: From the Queen of Sheba to the Advent of Islam, Markus Wiener, Princeton, NJ.

Sedov, A. V. (1992). New archaeological and epigraphical material from Qana. Arabian Archaeology and Epigraphy 3: 110-137.

Sedov, A. V. (1998). Qana' (Yemen) and the Indian Ocean: The archaeological evidence. In Ray, H. P., and Salles, J.-F. (eds.), Tradition and Archaeology: Early Maritime Contacts in the Indian Ocean, Manohar, New Delhi, pp. 11-35.

Sedov, A. V. (2005). Temples of Ancient Hadramawt, PLUS-Pisa University Press, Pisa.

Sedov, A. V. (2007). The port of Qana' and the incense trade. In Peacock, D., Williams, D., and James, S. (eds.), Food for the Gods: New Light on the Ancient Incense Trade, Oxbow, Oxford, pp. 71-111.

Sedov, A. V. (2010a). Les fouilles de secteur 3: la synagogue. In Salles, J. F., and Sedov, A. V. (eds.), Qani: le port antique du Hadramawt entre la Méditerranée, l'Afrique et l'Inde Fouilles russes 1972, 1985-1989, 1991, 1993-1994, Brepols, Turnhout, pp. 87-122.

Sedov, A. V. (2010b). Place of Qāni' in the Rome-Indian sea-trade. In Salles, J. F., and Sedov, A. V. (eds.), Qani: le port antique du Hadramawt entre la Méditerranée, l'Afrique et l'Inde Fouilles russes 1972, 1985-1989, 1991, 1993-1994, Brepols, Turnhout, pp. 453-474.

Sedov, A. V., and Benvenuti, C. (2002). The pottery of Sumhuram: General typology. In Avanzini, A. (ed.), Khor Rori Report I, Edizioni Plus, Pisa, pp. 177-248.

Seland, E. H. (2008). The Indian ships at Moscha and the Indo-Arabian trading circuit. Proceedings of the Seminar for Arabian Studies 38: 283-288.

Seland, E. H. (2010). Ports and Power in the Periplus: Complex Societies and Maritime Trade on the Indian Ocean in the First Century AD, BAR International Series 2102, Archaeopress, Oxford.

Seland, E. H. (2011). The Persian Gulf or the Red Sea? Two axes in ancient Indian Ocean trade, where to go and why. World Archaeology 43: 398-409.

Seland, E. H. (2012a). Death or taxes: Choosing itineraries between the Persian Gulf and the Mediterranean in the mid-18th century. Academic Quarter 4: 97-108.

Seland, E. H. (2012b). Trade and Christianity in the Indian Ocean during late antiquity. Journal of Late Antiquity 5: 72-86.

Seland, E. H. (2013). Networks and social cohesion in ancient Indian Ocean trade: Geography, ethnicity, religion. Journal of Global History 8: 373-390.

Selvakumar, V., Shajan, K. P., and Tomber, R. (2009). Archaeological investigations at Pattanam, Kerala: New evidence for the location of ancient Muziris. In Tomber, R., Blue, L., and Abraham, S. (eds.), Migration, Trade and Peoples, Part 1: Indian Ocean Commerce and the Archaeology of Western India, British Association for South Asian Studies, The British Academy, London, pp. 29-41.

Shajan, K. P., Tomber, R., Selvakumar, V., and Cherian, P. J. (2004). Locating the ancient port of Muziris, fresh findings from Pattinam. Journal of Roman Archaeology 17: 351-359.

Shinnie, P. L. (1960). Socotra. Antiquity 34: 100-110.

Shipton, C., Helm, R., Boivin, N., Crowther, A., Austin, P., and Fuller, D. Q. (2013). Intersections, networks and the genesis of social complexity on the Nyali coast of East Africa. African Archaeological Review 30: 1-27.

Sidebotham, S. E. (2002). Late Roman Berenike. Journal of the American Research Center in Egypt 39: 217-240.

Sidebotham, S. E. (2004). Reflections of ethnicity in the Red Sea commerce in antiquity: Evidence of trade goods, languages and religions from the excavations at Berenike. In Lunde, P., and Porter, A. (eds.), Trade and Travel in the Red Sea Region, BAR International Series 1269, Archaeopress, Oxford, pp. 105-115.

Sidebotham, S. E. (2011). Berenike and the Ancient Maritime Spice Route, University of California Press, Berkeley.

Sidebotham, S. E. (2012). The Red Sea and the Indian Ocean in the age of the great empires. In Potts, D. T. (ed.), A Companion to the Archaeology of the Ancient Near East, Blackwell, Malden MA, pp. 1041-1059. 
Sidebotham, S. E., and Wendrich, W. Z. (1995). Berenike 1994: Preliminary Report of the 1994 Excavations at Berenike (Egyptian Red Sea Coast) and the Survey of the Eastern Desert, CNWS, Leiden.

Sidebotham, S. E., and Wendrich, W. Z. (1996). Berenike 1995: Preliminary Report of the 1995 Excavations at Berenike (Egyptian Red Sea Coast) and the Survey of the Eastern Desert, CNWS, Leiden.

Sidebotham, S. E., and Wendrich, W. Z. (1998). Berenike 1996: Report of the 1996 Excavations at Berenike (Egyptian Red Sea coast) and the Survey of the Eastern Desert, CNWS, Leiden.

Sidebotham, S. E., and Wendrich, W. Z. (1999). Berenike 1997: Report of the 1997 Excavations at Berenike and the Survey of the Egyptian Eastern Desert, including Excavations at Shenshef, CNWS, Leiden.

Sidebotham, S. E., and Wendrich, W. Z. (2000). Berenike 1998: Report of the 1998 Excavations at Berenike and the Survey of the Egyptian Eastern Desert, including Excavations in Wadi Kalalat, CNWS, Leiden.

Sidebotham, S. E., and Wendrich, W. Z. (2007). Berenike 1999/2000: Report on the Excavations at Berenike, including Excavations in Wadi Kalalat and Siket, and the Survey of the Mons Smaragdus Region, Cotsen Institute of Archeaology, University of California, Los Angeles.

Sidebotham, S. E., and Zych, I. (2010). Berenike: Archaeological fieldwork at a Ptolemaic-Roman port on the Red Sea coast of Egypt 2008-2010. Sahara: Preistoria e Storia del Sahara 21: 7-28.

Sidebotham, S. E., and Zych, I. (eds.) (2011). Berenike 2008-2009: Report on the Excavations at Berenike, including a Survey in the Eastern Desert, Polish Centre of Mediterranean Archaeology, University of Warsaw, Warsaw.

Sidebotham, S. E., and Zych, I. (2012a). Berenike: Archaeological fieldwork at a Ptolemaic-Roman port on the Red Sea coast of Egypt 2011-2012. Sahara: Preistoria e Storia del Sahara 23: 29-48.

Sidebotham, S. E., and Zych, I. (2012b). Results of fieldwork at Bernike on the Red Sea coast of Egypt, 2008-2010. Topoi Supplément 11: 133-157.

Sidebotham, S. E., Hense, M., and Nouwens, H. M. (2008). The Red Land: The Illustrated Archaeology of Egypt's Eastern Desert, American University in Cairo Press, Cairo.

Simpson, S. J. (ed.) (2002). Queen of Sheba, British Museum Press, London.

Sinclair, P. (1982). Chibuene: An early trading station in southern Mozambique. Paideuma 28: 149-164.

Smith, M. (2002). The role of local trade networks in the Indian subcontinent during the Early Historic period. Man and Environment 27: 139-151.

Smith, M. C., and Wright, H. T. (1988). The ceramics from Ras Hafun in Somalia: Notes on a classical maritime site. Azania 23: 115-141.

Steve, M. J. (2003). L'Ile de Kharg: une page de l'histoire du Golfe persique et du monachisme oriental, Recherches et Publications, Neuchâtel.

Strauch, I. (2012). Foreign Sailors on Socotra: The Inscriptions and Drawings from the Cave Hoq, Hempen, Bremen.

Strauch, I., and Bukharin, M. D. (2004). Indian inscriptions from the cave Hoq on Suquțāa (Yemen). AION 46: $121-138$.

Sundström, R. (1907). Report on an expedition to Adulis. Zeitschrift für Assyriologie 20: 171-182.

Thomas, R. (2012). Port communities and the Erythraean Sea trade. British Museum Studies in Ancient Egypt and Sudan 18: 170-199.

Tomber, R. (2000). Indo-Roman trade: The ceramic evidence from Egypt. Antiquity 74: 624-631.

Tomber, R. (2005). Aksumite and other imported ceramics from early historic Kamrej. Journal of Indian Ocean Archaeology 2: 99-102.

Tomber, R. (2007a). Bishops and traders: The role of Christianity in the Indian Ocean during the Roman period. In Starkey, J., Starkey, P., and Wilkinson, T. (eds.), Natural Resources and Cultural Connections of the Red Sea, BAR International Series 1661, Archaeopress, Oxford, pp. 219-226.

Tomber, R. (2007b). Rome and Mesopotamia: Importers into India in the first millennium AD. Antiquity 81: $972-988$.

Tomber, R. (2008). Indo-Roman Trade, From Pots to Pepper, Duckworth, London.

Tomber, R. (2009). Beyond western India: The evidence from imported amphorae. In Tomber, R., Blue, L., and Abraham, S. (eds.), Migration, Trade and Peoples. Part 1: Indian Ocean Commerce and the Archaeology of Western India, British Association for South Asian Studies, The British Academy, London, pp. 42-57. 
Tomber, R. (2011). 2: Pots with writing. In Blue, L., and Peacock, D. (eds.), Myos Hormos - Quseir alQadim. Roman and Islamic Ports on the Red Sea, Volume 2: Finds from the Excavations 1999-2003, BAR International Series 2286, Archaeopress, Oxford, pp. 5-10.

Tomber, R. (2012). From the Roman Red Sea to beyond the empire: Egyptian ports and their trading partners. British Museum Studies in Ancient Egypt and Sudan 18: 201-215.

Tripathi, A. (2004). Onshore and offshore explorations in Elephanta Island: Evidence of IndoMediterranean trade. Journal of Indian Ocean Archaeology 1: 116-123.

Turner, P. J. (1989). Roman Coins from India, Royal Numismatic Society, London.

Varadarajan, L. (1995). Indian boat building traditions: The ethnological evidence. In Boussac, M.-F., and Salles, J.-F. (eds.), Athens, Aden, Arikamedu: Essays on the Interrelation between India, Arabia and the Eastern Mediterranean, Manohar, New Delhi, pp. 167-192.

Veen, M., Breunig, P., and Neumann, K. (2011a). Consumption, Trade and Innovation: Exploring the Botanical Remains from the Roman and Islamic Ports at Quseir al-Qadim, Egypt, Africa-MagnaVerlag, Frankfurt.

Veen, M., Cox, A., and Morales, J. (2011b). 18: The plant remains: Evidence for trade and cuisine. In Blue, L., and Peacock, D. (eds.), Myos Hormos-Quseir al-Qadim. Roman and Islamic Ports on the Red Sea, Volume 2: Finds from the Excavations 1999-2003, BAR International Series 2286, Archaeopress, Oxford, pp. 227-234.

Villeneuve, F. (2004). Une inscription latine sur l'archipel Farasân, Arabie Séoudite, sud de la mer Rouge. Comptes Rendus de l'Académie des Inscriptions et Belles-Lettres 148: 419-429.

Villeneuve, F. (2005-2006). Farasân inscriptions and Bukharin's ideas: No pontifex Herculis and other comments. Arabia 3: 289-296.

Villeneuve, F. (2007). L'armée romaine en mer Rouge aux IIe-IIIe siècles après J.-C.: à propos des inscriptions de Farasân. In Lewin, A., and Pellegrini, P. (eds.), The Late Roman Army in the Near East from Diocletian to the Arab Conquest: Proceedings of a Colloquium Held at Potenza, Acerenza and Matera, Italy (May 2005), BAR International Series 1717, Archaeopress, Oxford, pp. 13-27.

Vincent, W. (1998). The Commerce and Navigation of the Ancients in the Indian Ocean, Asian Educational Services, New Delhi (reprint of the 1807 edition).

Vinogradov, Y. A. (2011). An important archaeological discovery on the island Socotra. Vestnik Drevnej Istorii 4: $99-105$.

Walz, J. R., and Brandt, S. A. (2006). Toward an archaeology of the other African diaspora: The slave trade and dispersed Africans in the western Indian Ocean. In Haviser, J. B., and MacDonald, K. C. (eds.), African Re-Genesis: Confronting Social Issues in the Diaspora, Left Coast Press, Walnut Creek, CA, pp. 246-268.

Walz, J. R., and Gupta, S. (2013). Indian Ocean cosmopolitanism in antiquity: The archaeological clues, with special reference to first millennium CE ceramics. In Cheyssial, A. (ed.), Entretiens du patrimoine de l'Ocean Indien, École Nationale Supérieure D'architecture de Montpellier, Montpelier, pp. 43-51.

Ward, W. (2007). Aila and Clysma: The rise of northern ports in the Red Sea in late antiquity. In Starkey, J., Starkey, P., and Wilkinson, T. (eds.), Natural Resources and Cultural Connections of the Red Sea, BAR International Series 1661, Archaeopress, Oxford, pp. 161-171.

Warmington, E. H. (1995). The Commerce Between the Roman Empire and India, Munshiram Manoharlal, New Dehli (reprint of the 1928 edition).

Weeks, L., Morris, M., McCall, B., and al-Zubayri, K. (2002). A recent archaeological survey on Soqotra: Report on the preliminary expedition season January 5th-February 2nd, 2001. Arabian Archaeology and Epigraphy 13: 95-125.

Weerakkody, D. P. (1997). Taprobanê: Ancient Sri Lanka as Known to Greeks and Romans, Brepols, Turnhout.

Wellsted, J. R. (1838). Travels in Arabia, J. Murray, London.

Wellsted, J. R., and Ormsby, L. (1840). Travels to the City of the Caliphs, along the Shores of the Persian Gulf and the Mediterranean, Including a Voyage to the Coast of Arabia, and a Tour on the Island of Socotra, H. Colburn, London.

Wendrich, W. Z., Tomber, R. S., Sidebotham, S. E., Harrel, J. A., Cappers, R. T., and Bagnall, R. S. (2003). Berenike crossroads: The integration of information. Journal of the Economic and Social History of the Orient 46: 46-87.

Wheeler, M. (1955). Rome Beyond the Imperial Frontiers, Penguin Books, Middlesex.

Wheeler, M., Gosh, A., and Deva, K. (1946). Arikamedu: An Indo-Roman trading-station on the east coast of India. Ancient India 2: 17-38. 
Whitcomb, D. S. (2001). Ceramic production at Aqaba in the Early Islamic period. In Villeneuve, E., and Watson, P. M. (eds.), La céramique Byzantine et proto-Islamique en Syrie-Jordanie (IVe-VIIIe siècles ap. J.-C.): Actes du colloque à Amman, 3-5 décembre 1994, Institut Francais d'Archaeologie du Proche-Orient, Beirut, pp. 296-303.

Whitcomb, D. S., and Johnson, J. H. (1979). Quseir al-Qadim 1978: Preliminary Report, American Research Center in Egypt, Cairo.

Whitcomb, D. S., and Johnson, J. H. (1982). Quseir al-Qadim 1980: Preliminary Report, Undena Publications, Malibu, CA.

Whitehouse, D. (1989). Begram, the Periplus and Gandharan art. Journal of Roman Archaeology 2: 93-100.

Whitehouse, D. (1996). Sasanian maritime activity. In Reade, J. (ed.), The Indian Ocean in Antiquity, Kegan Paul International, London, pp. 339-349.

Whitehouse, D. (2001). Begram: The glass. Topoi: Orient-Occident 11: 437-449.

Whitehouse, D., and Williamson, A. (1973). Sasanian maritime trade. Iran 11: 29-49.

Whitehouse, D., Brill, R. H., and Haerinck, E. (1998). The Glass Vessels, Peeters, Leuven.

Whitewright, J. (2007a). How fast is fast? Technology, trade and speed under sail in the Roman Red Sea. In Starkey, J., Starkey, P., and Wilkinson, T. (eds.), Natural Resources and Cultural Connections of the Red Sea, BAR International Series 1661, Archaeopress, Oxford, pp. 77-87.

Whitewright, J. (2007b). Roman rigging material from the Red Sea port of Myos Hormos. International Journal of Nautical Archaeology 36: 282-292.

Wild, F. C., and Wild, J. P. (2001). Sails from the Roman port of Berenike. International Journal of Nautical Archaeology 30: 211-220.

Wild, J. P., and Wild, F. C. (2007). Chapter 11: Textiles. In Sidebotham, S. E., and Wendrich, W. Z. (eds.), Berenike 1999/2000, Cotsen Institute of Archaeology, University of California, Los Angeles, pp. 225-227.

Wilding, R. F. (1989). The pottery. In Munro-Hay, S. (ed.), Excavations at Aksum, The British Institute in Eastern Africa, London, pp. 235-316.

Will, E. L. (2004). Mediterranean amphoras in India. In Eiring, J., and Lund, J. (eds.), Transport Amphorae and Trade in the Eastern Mediterranean; Acts of the International Colloquium at the Danish Institute at Athens, September 26-29, 2002, Aarhus University Press, Aarhus, pp. 433-441.

Wood, M. (2012). Interconnections: Glass Beads and Trade in Southern and Eastern Africa and the Indian Ocean-7th to 16th centuries AD, Uppsala University, Uppsala.

Yoffee, N. (2005). Myths of the Archaic State: Evolution of the Earliest Cities, States, and Civilizations, Cambridge University Press, Cambridge.

Yule, P. (1993). More than Samad in Oman: Iron Age pottery from Suhar and Sumhuram. Arabian Archaeology and Epigraphy 4: 69-106.

Zazzaro, C. (2013). The Ancient Red Sea Port of Adulis and the Eritrean Coastal Region: Previous Investigations and Museum Collections, BAR International Series 2569, Archaeopress, Oxford.

Zazzaro, C., and Manzo, A. (2012). A preliminary assessment on the pottery assemblage from the port town of Adulis (Eritrea). British Museum Studies in Ancient Egypt and Sudan 18: 233-246.

\section{Bibliography of recent literature}

Agius, D. A. (2013). Ships that sailed the Red Sea in medieval and early modern Islam: Perception and Reception. In Porter, V., and Saif, L. (eds.), The Hajj: Collected Essays, British Museum Press, London, pp. 84-95.

Agius, D. A., Cooper, J. P., Trakadas, A., and Zazzaro, C. (eds.) (2012). Navigated Spaces, Connected Places: Proceedings of Red Sea Project V Held at the University of Exeter 16-19 September 2010, BAR International Series 2346, Archaeopress, Oxford.

Bang, P. F. (2008). The Roman Bazaar: A Comparative Study of Trade and Markets in a Tributary Empire, Cambridge University Press, Cambridge.

Bard, K. A., and Fattovich, R. (eds.) (2007). Harbour of the Pharaohs to the Land of Punt: Archaeological Investigations at Mersa Gawasis Egypt, 2001-2005, Universitá degli studi di Napoli "L'Orientale," Naples.

Begley, V., and De Puma, R. D. (eds.) (1991). Rome and India, the Ancient Sea Trade, University of Wisconsin Press, Madison. 
Blue, L., Cooper, J., Thomas, R., and Whitewright, J. (eds.) (2009). Connected Hinterlands: Proceedings of Red Sea Project IV Held at the University of Southampton September 2008, BAR International Series 2052, Archaeopress, Oxford.

Boivin, N., and Fuller, D. Q. (2009). Shell middens, ships and seeds: Exploring coastal subsistence, maritime trade and the dispersal of domesticates in and around the ancient Arabian Peninsula. Journal of World Prehistory 22: 113-180.

Boussac, M.-F., and Salles, J.-F. (eds.) (1995). Athens, Aden, Arikamedu: Essays on the Interrelations between India, Arabia and the Eastern Mediterranean, Manohar, Delhi.

Boussac, M.-F., and Salles, J.-F. (eds.) (2005). A Gateway from the Eastern Mediterranean to India: The Red Sea in Antiquity, Manohar, New Delhi.

Boussac, M.-F., Salles, J.-F., and Yon, J.-B. (eds.) (2012). Topoi, Supplément 11: Autour du Périple de la mer Érythrée, Maison de l'Orient et la Méditerranée, Jean Poilloux, Lyon.

Bowersock, G. W. (2013). Throne of Adulis: Red Sea Wars on the Eve of Islam, Oxford University Press, Oxford.

Breen, C., and Lane, P. (2004). Archaeological approaches to East Africa's changing seascapes. World Archaeology 35: 469-489.

Christides, V. (2003). What went wrong in the long distance Roman naval power in the Red Sea and in the Indian Ocean in the late third century AD. In Samir, K. S., and Monferrer-Sala, J. P. (eds.), Graeco-latina et Orientalia: studia in honorem angeli urbani heptagenarii, Oriens Academic, Cordoba, pp. 63-86.

Cimino, R. M. (ed.) (1994). Ancient Rome and India: Commercial and Cultural Contacts between the Roman World and India, Istituto Italiano per il Medio ed Estremo Oriente and Italian Embassy Cultural Centre, Rome.

Cleuzieu, S. (1992). The prehistoric origins of seafaring along the Oman coast. In Al-Lawaty, M. (ed.), United Nations Educational, Scientific, and Cultural Organization (UNESCO) Project to Study the Silk Routes: Papers Submitted at the International Seminar on the Silk Roads Held at Sultan Qaboos University, Muscat, Sultanate of Oman, 20-21 November 1990, Ministry of National Heritage and Culture, Muscat, pp. 20-22.

Cohen, G. M. (2006). The Hellenistic Settlements in Syria, the Red Sea Basin, and North Africa, University of California Press, Berkeley.

De Romanis, F. (1996). Cassia, Cinnamono, Ossidiana, Bretschneider, Rome.

De Romanis, F., and Tchernia, A. (eds.) (1997). Crossings: Early Mediterranean Contacts with India, Manohar, New Delhi.

Dussubieux, L., Kusimba, C. M., Gogte, V., Kusimba, S. B., Gratuze, B., and Oka, R. (2008). The trading of ancient glass beads: New analytical data from South Asian and East African soda-alumina glass beads. Archaeometry 50: 797-821.

Fattovich, R. (2005). Marsa Gawasis: A Pharaonic coastal settlement by the Red Sea in Egypt. In Starkey, J. C. M. (ed.), People of the Red Sea: Proceedings of the Red Sea Project II, Held in the British Museum, October 2004, BAR International Series 1395, Archaeopress, Oxford, pp. 15-22.

Fitzpatrick, M. P. (2011). Provincializing Rome: The Indian Ocean trade network and Roman imperialism. Journal of World History 22: 27-54.

Gupta, S. (2002). The archaeo-historical idea of the Indian Ocean. Man and Environment 27: 2-24.

Gurukkal, R. (2013). Classical Indo-Roman trade: A historiographical reconsideration. Indian Historical Review 40: 181-206.

Jha, A., and MacDowall, D. W. (eds.) (2004). Foreign Coins Found in the Indian Sub-Continent, Indian Institute of Research in Numismatic Studies, Nasik.

Kennedy, K. A., and Possehl, G. L. (2012). Were there commercial communications between prehistoric Harappans and African populations? Advances in Anthropology 2: 169-180.

Kenoyer, J. M. (2007). Indus and Mesopotamian trade networks: New insights from shell and carnelian artifacts. Intercultural Relations between South and Southwest Asia: Studies in Commemoration of ECL During-Caspers (1934-1996) 1826: 19-28.

Kenoyer, J. M., Price, T. D., and Burton, J. H. (2013). A new approach to tracking connections between the Indus Valley and Mesopotamia: Initial results of strontium isotope analyses from Harappa and Ur. Journal of Archaeological Science 40: 2286-2297.

Kusimba, C., and Kusimba, S. B. (2011). East African Archaeology: Foragers, Potters, Smiths, and Traders, University of Pennsylvania Press, Philadelphia.

Lane, P. (2012). Maritime and shipwreck archaeology in the western Indian Ocean and southern Red Sea: An overview of past and current research. Journal of Maritime Archaeology 7: 9-41. 
Lunde, P., and Porter, A. (eds.) (2004). Trade and Travel in the Red Sea Region: Proceedings of the Red Sea Project I Held in the British Museum, October 2002, BAR International Series 1269, Archaeopress, Oxford.

Magee, P. (2010). Iran and the Gulf in the first half of the first millennium BCE. In Avanzini, A. (ed.), Eastern Arabia in the First Millennium BCE, L'Erma di Bretschneider, Pisa, pp. 45-56.

Manguin, P.-Y., Mani, A., and Wade, G. (2011). Early Interactions Between South and Southeast Asia: Reflections on Cross-cultural Exchange, Institute of Southeast Asian Studies, Singapore.

McLaughlin, R. (2010). Rome and the Distant East: Trade Routes to the Ancient Lands of Arabia, India and China, Continuum, London.

Munro-Hay, S. (2003). Coinage of Arabia Felix: The Pre-Islamic Coinage of the Yemen, Edizioni Ennerre, Milan.

Parker, G. (2002). Ex oriente luxuria: Indian commodities and Roman experience. Journal of the Economic and Social History of the Orient 45: 40-95.

Parker, G. (2008). The Making of Roman India, Cambridge University Press, Cambridge.

Phillips, J. (1997). Punt and Aksum: Egypt and the horn of Africa. Journal of African Studies 38: 423-457.

Pomey, P. (2012). À propos des navires de la mer Érythrée: découvertes récentes et noveaux aspects de la question Topoi Supplément 11: 111-132.

Possehl, G. L. (1997). Seafaring merchants of Meluhha. South Asian Archaeology 1995: 87-100.

Potts, D. T. (1990). The Arabian Gulf in Antiquity, Oxford University Press, Oxford.

Rathbone, D. (2000). The 'Muziris' papyrus (SB XVIII 13167): Financing Roman trade with India. Bulletin de la Société Archéologique d'Alexandrie 46: 39-50.

Ray, H. P. (1994). The Winds of Change: Buddhism and the Maritime Links of Early South Asia, Oxford University Press, Delhi.

Ray, H. P. (ed.) (1999). Archaeology of Seafaring: The Indian Ocean in the Ancient Period, Pragati Publications, Delhi.

Ray, H. P., and Salles, J.-F. (eds.) (1998). Tradition and Archaeology: Early Maritime Contacts in the Indian Ocean, Manohar, New Delhi.

Reade, J. (ed.) (1996). The Indian Ocean in Antiquity, Kegan Paul International, London.

Roth, H., Kessler, O., Recker, U., and Wijeyapala, W. (2001). The Godavaya harbour site: Report on the 1994-1997 excavations. In Weisshaar, H.-J., Roth, H., and Wijeyapala, W. (eds.), Ancient Ruhuna: Sri Lankan-German Archaeological Project in the Southern Province, Verlag Philipp von Zabern, Mainz, pp. 291-326.

Seland, E. H. (ed.) (2007). The Indian Ocean in the Ancient Period: Definite Places, Translocal Exchange, BAR International Series 1593, Archaeopress, Oxford.

Seland, E. H. (2008). The Indian Ocean and the globalisation of the ancient world. Ancient West and East 7: $67-79$.

Smith, M. L. (1999). "Indianization" from the Indian point of view: Trade and cultural contacts with Southeast Asia in the early first millennium CE. Journal of the Economic and Social History of the Orient 42: 1-26.

Somadeva, R. (2006). Urban Origins in Southern Sri Lanka, Department of Archaeology and Ancient History, Uppsala University, Uppsala.

Starkey, J. (ed.) (2005). People of the Red Sea: Proceedings of Red Sea Project II, Held in the British Museum, October 2004, BAR International Series 1395, Archaeopress, Oxford.

Starkey, J., Starkey, P., and Wilkinson, T. J. (eds.) (2007). Natural Resources and Cultural Connections of the Red Sea, BAR International Series 1661, Archaeopress, Oxford.

Tomber, R., Cartwright, C., and Gupta, S. (2011). Rice temper: Technological solutions and source identification in the Indian Ocean. Journal of Archaeological Science 38: 360-366.

Walz, R. J. (2013). Routes to history: Archaeology and being articulate in eastern Africa. In Schmidt, P. R., and Mrozowski, S. A. (eds.), The Death of Prehistory, Oxford University Press, Oxford, pp. 69-91.

Ward, C., and Zazzaro, C. (2010). Evidence for Pharaonic seagoing ships at Mersa/Wadi Gawasis, Egypt. International Journal of Nautical Archaeology 39: 27-43.

Weisshaar, H.-J., Roth, H., and Wijeyapala, W. (eds.) (2001). Ancient Ruhuna: Sri Lankan-German Archaeological Project in the Southern Province, Verlag Philipp von Zabern, Mainz.

Wilkens, B. (2002). The consumption of animal products at Sumhuram. In Avanzini, A. (ed.), Khor Rori Report I, Edizioni Plus, Pisa, pp. 271-322. 
Young, G. K. (2001). Rome's Eastern Trade: International Commerce and Imperial Policy, 31 BC-AD 305, Routledge, London.

Yule, P. (2013). A late antique Christian king from Zafar, southern Arabia. Antiquity 87: 1124-1135. 